How do oil producers respond to giant oil field discoveries?

by

Jochen GÜNTNER

Working Paper No. 1704

March 2017

Johannes Kepler University of Linz Department of Economics Altenberger Strasse 69 A-4040 Linz - Auhof, Austria www.econ.jku.at 


\title{
How do oil producers respond to giant oil field discoveries?
}

\author{
Jochen H. F. Güntner* \\ Johannes Kepler University Linz
}

March 15, 2017

\begin{abstract}
This paper studies how petroleum producers respond to a giant oil field discovery. Using a large panel of country-level production data and a difference-in-differences identification approach, I show that domestic production levels respond before a newly found oil field has come on line, indicating that producers raise extraction rates from existing reservoirs. Given that domestic petroleum consumption rises by less in response to a discovery, at least part of the increase in production seems to go into (net) oil exports. I find substantial heterogeneity in the impulse responses of oil production and consumption with respect to the location and size of a giant oil field and the country's OPEC membership status.
\end{abstract}

Keywords: Giant oil field discoveries; Half life of reserves; Oil production; OPEC; Proved reserves

JEL Classification: C32, N50, Q33, Q41

*Jochen Güntner is Assistant Professor at the Department of Economics, Johannes Kepler University Linz. Address: Altenbergerstrasse 69, 4040 Linz-Auhof, Austria. E-mail: jochen.guentner@jku.at, Telephone: +43732 2468 8360. Fax: +43732 24689679. 


\section{Introduction}

Given that the average delay between a reserves discovery and production is four to six years, Aretzki et al. (2017) use giant oil and gas field discoveries as a directly observable measure of news shocks about future output to explore the effects of such shocks in an open economy. In a large panel of countries, the authors find that - consistent with the predictions of a theoretical two-sector small open economy model with a resource sector - the current account and savings decline for the first five years before rising sharply during the following years. Investment rises shortly after the discovery, whereas GDP does not increase until after five years. Employment falls slightly and remains low for a sustained period of time.

The classical Hotelling model predicts that the optimal level of extraction increases directly after an unexpected resource discovery. In contrast, the analysis in Aretzki et al. (2017) rests on the assumption of a given extraction path from the newly found reservoir, while the possibility of adjusting production from existing reservoirs is discarded on the basis of high adjustment costs in oil and gas production (see, e.g., Hamilton, 2009; Kilian, 2009). Focusing on giant oil field discoveries from the same data set and annual panel data on petroleum production starting in 1965, I find that country-level production picks up soon after the discovery of a large oil field, while the level of statistical significance of the corresponding impulse response function depends on the exact specification of the dynamic panel distributed lag regression model.

Using information about the size, type, and location of oil fields, I show that the subsequent increase in petroleum production arises mainly from so-called "super-" and "mega-giant" fields with an estimated ultimate recovery of three billion barrels of oil equivalents (bboe) as opposed to ordinary "giant" fields, that production increases in response to offshore rather than onshore discoveries, and that non-OPEC producers tend to raise domestic production levels significantly in response to a discovery, whereas OPEC members seem to postpone production from newly discovered as well as existing reservoirs. This is consistent with prior findings in Güntner (2014) regarding the response of OPEC producers to oil demand shocks.

Using a large panel of country-level consumption data starting in 1965, I further investigate whether the observed hike in petroleum production is accompanied by a quantitatively similar increase in petroleum consumption or rather destined for raising (net) oil exports, as implicitly assumed in Aretzki et al. (2017). Based on a sample of 172 countries, I find that country-level consumption also increases in response to a giant oil field discovery - albeit by quantitatively less than production and at a lower level of statistical significance. Interestingly, consumption increases significantly for non-OPEC producers, whereas it decreases significantly or remains unchanged for OPEC member states, depending on the exact specification of the dynamic panel 
distributed lag regression model.

My study is closely related to Lepore and Rastad (2011), who use discrete changes in proved reserves and oil production data from the British Petroleum (BP) Statistical Review of World Energy to investigate the response of petroleum producers to oil discoveries during 1980-2009. Relative to their study, the present paper has three important advantages. First, starting in 1965 rather than in 1980, my sample adds 15 years of data, which account for a substantial share of newly discovered oil reserves since the 1960s, as illustrated in Figure1. Second, oil discoveries in this paper correspond to externally validated and exactly dated findings of giant oil fields rather than to "large changes" in proved oil reserves according to some arbitrary threshold chosen by the authors. This is crucial because proved reserves are defined as reservoirs for which "economic producibility is supported by actual production or conclusive formation tests (drill stem or wire line) or [...] by core analyses and/or electric or other interpretations.' 11 In particular, the amount of proved reserves is subject to the current oil price and available production techniques. As a consequence, the data set in Lepore and Rastad (2011) also contains large reductions in proved reserves, which cannot be explained by depletion due to production and are therefore excluded in one of their robustness check. Third, this study draws on the exact size of a newly discovered giant oil field in terms of its estimated ultimate recovery of oil in order to quantify the economic significance of each discovery, whereas Lepore and Rastad (2011) compute a dummy variable that takes on a value of one in the year of a large change in proved oil reserves and zero in all other years, effectively treating the 2009 discoveries of the 9 bboe super-giant Libra field in Brazil and the 0.75 bboe giant Tiber field in the U.S. Mexican Gulf as one and the same event. Finally, the use of a panel distributed lag regression model, as in Aretzki et al. (2017), facilitates the computation of dynamic impulse response functions beyond the analysis of selected regression coefficients, as in Lepore and Rastad (2011).

\section{Related Literature}

In the classic Hotelling (1931) model, the stock of an exhaustible resource is assumed to be known with certainty. Absent extraction costs, the shadow value of the resource should therefore rise over time at the market rate of interest, while all future prices and the optimal extraction path are determined by the initial price. Yet, the theoretical prediction of an upward-sloping price path seems inconsistent with the empirical observation of falling prices for many mineral commodities over much of the twentieth century. While there are many possible explanations for this discrepancy, one obvious candidate is that the resource base is not known with certainty

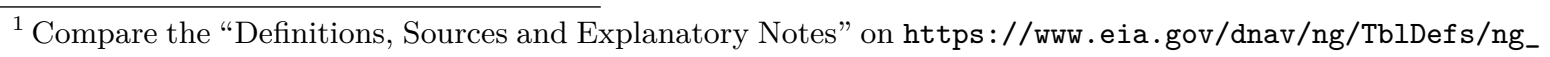
enr_nprod_tbldef2.asp.
} 
from the beginning. Instead, repeated downward revisions of the initial price due to unexpected resource discoveries might offset the predicted rise at the market rate of interest (compare Arrow and Chang, 1982). The present paper is related to three strands of the subsequent literature.

\subsection{Exploration and extraction}

First, the theoretical and empirical analysis of oil producers' optimal exploration and extraction activity. Peterson (1978) develops a model with extractive firms, which select the time paths of exploration and extraction that maximize their present value. Simulating industry behavior under competition, monopoly, and central management, the authors find that a monopolist will over-conserve the resource and hold excess reserves, whereas competitors over-explore and overextract. Pindyck (1980) introduces demand and reserve uncertainty in a simple model of an exhaustible resource market by modeling fluctuations in the demand function and the reserve base as continuous-time stochastic processes. With constant extraction costs and risk-neutral firms, neither demand nor reserve uncertainty affects the price and the Hotelling rule continues to apply both in competitive and monopolistic markets. When extraction costs are a function of the level of reserves, however, reserve uncertainty influences the expected price dynamics. Arrow and Chang (1982) assume that the distribution of a natural resource across an unexplored territory follows a Poisson process in space. At any point in time, the socially optimal rates of consumption and exploration are chosen, assuming that reserves are depleted by consumption and increased by resource discoveries from exploration, which reduces the remaining unexplored land. The authors show that, for a large amount of unexplored land, the shadow values of land and reserves move in random cycles with only a slight upward trend, possibly explaining the failure of the so-called Hotelling rule described above.

Farrow (1985) tests whether the theoretical, privately efficient extraction path is consistent with the observed behavior of an individual mining firm. Using proprietary firm data, output price data, and an estimated trans-log cost system to compare changes in the in-situ value with the expected price path, the theoretical model is rejected even when allowing for a time-varying discount rate, an alternative expected price series, or a constraint on the rate of output. Pesaran (1990) explicitly accounts for the intertemporal nature of exploration and production decisions in the oil discovery process by deriving theoretically consistent exploration and production equations for price-taking suppliers. Applying his econometric framework to the U.K. Continental Shelf, in contrast to prior studies, significant price effects on oil production and exploration are found. In a similar vein, Farzin (2001) develops a model of additions to proved reserves that explicitly incorporates the effects of expected resource price, cumulative reserves development, and technological progress. Applying the model to U.S. data for 1950-1995, the author finds a 
statistically significant but rather small price elasticity of reserve additions. Assuming steady economic growth and oil consumption, ceteris paribus, an annual oil price increase of 1.5-4.5\% is necessary to stabilize U.S. oil import dependence in the future. Using data for three separate regions of the Norwegian Continental Shelf for 1965-2004 to estimate error-correction models that capture the longer-term relationships between drilling efforts and geological and technology variables, Mohn and Osmundsen (2008) also find robust evidence of long-term oil price effects on exploration activity in a highly regulated petroleum province.

\subsection{Supply from existing reservoirs}

Separating production from existing wells in a known oil field from the drilling of new wells and incorporating geological and engineering motives in a model of oil supply from known reserves, Black and LaFrance (1998) test the so-called maximum efficiency recovery (MER) hypothesis that production from established fields is invariant to the price of oil. When applying their econometric model to quarterly data from seven Montana oil fields, the MER hypothesis is strongly rejected. In contrast, Thompson (2001) refers to the "practitioner literature", which suggests that the owners of an undeveloped resource possess compound options on information acquisition, exploration, and development drilling, whereas the daily production decisions from developed reserves resemble a corner solution. The optimal rate of production is near capacity, primarily because the marginal cost per barrel is constant and far below the market price of oil, while "backwardation" provides the incentive to drill and replace developed reserves ${ }^{2}$

Pickering (2008) considers the relationship between extraction rates and remaining reserves. In a simple exhaustible resources model, the slope of a linear extraction rule is determined by the producers' discount factor, whereas differences in cost and pricing behavior affect the intercept term. The reserves-production relationship is born out by panel data from the world oil industry both across countries and through time. While extraction is characterized by a robust and stable relationship over large ranges of remaining reserves, the estimated slope is significantly lower for OPEC member states. Pickering (2008) argues that this could be explained by differences in risk aversion, discount rates, and measurement error in the reserves data.

Spiro (2014) shows that, by removing any scarcity considerations of the resource owner, the assumption of a rolling planning horizon can reconcile the puzzling long-run price dynamics of exhaustible resources such as oil, gas, and metals. As a result, extraction can be non-decreasing and resource prices non-increasing for a long period of time. A calibration of the model to the oil market replicates the gradually falling real price of oil after WWII and the sharply increasing

\footnotetext{
2 Backwardation means that the discounted futures price of a commodity is below the spot price. While this appears to be inconsistent with the Hotelling principle under certainty, Litzenberger and Rabinowitz (1995) argue that backwardation reflects the option value of choosing the timing of production from developed reserves.
} 
price after 1998, suggesting that long-run scarcity has recently become more important.

\subsection{Effects of giant oil field discoveries}

The size and arguably exogenous timing of resource discoveries make them an ideal instrument for identifying the effects of an anticipated resource boom. As a consequence, the present paper is related to a small number of recent studies that investigate the impact of giant oil (and gas) discoveries on selected economic and political variables.

In a descriptive study, Höök et al. (2009) find that the average decline rate of the world's largest oil fields, which depends on new exploration and production technologies, is increasing over time. Given that these fields represent the most important production base and that the decline rate of existing giant oil fields is already high and increasing, the authors argue that the world faces an increasing oil supply challenge in the future.

Tsui (2009) exploits exogenous variation in the timing and size of giant oil discoveries to identify the impact of changes in oil wealth on democracy and finds that a discovery of 100 billion barrels of crude oil — roughly equal to the initial endowment of Iraq — pushes a country's level of democracy almost twenty percentage points below trend after three decades. While the effect is larger for fields with higher-quality oil and lower exploration and extraction costs, it is less precisely estimated when the discovery's size is measured per capita, suggesting that politicians care about the absolute rather than the per-capita value of a country's oil wealth.

Finally, Harding et al. (2016) estimate the effects of giant oil and gas discoveries on bilateral exchange rates and find that a discovery with a value equal to the country's GDP leads to a real exchange rate appreciation by $14 \%$ within ten years following the discovery that is driven almost exclusively by non-tradable goods inflation. These results are qualitatively and quantitatively consistent with the predictions of a calibrated model with forward-looking behavior and Dutchdisease dynamics.

\section{The Data}

\subsection{Giant oil fields of the world}

In order to analyze the response of petroleum producers to a credibly exogenous change in crude oil reserves, I use a data set of giant oil and gas field discoveries compiled by Myron K. Horn, former President of the American Association of Petroleum Geologists (AAPG), which contains information about the name, deposit type (i.e. oil or gas), discovery year, hydrocarbon volumes, reservoir depth, and reservoir location of close to 1,000 oil and gas fields discovered worldwide between 1868 and 2010. In what follows, I focus on the 590 giant, super-giant, and mega-giant 
oil field discoveries in Horn's (2014) data, which are particularly suitable for our study. Figure 1 plots the hydrocarbon volumes of giant oil fields cumulated by discovery year for 1900-2010.

The research question of this paper is how oil producers react to an increase in their reserves base and whether the OPEC status of the country or the location (i.e. onshore vs. offshore) and size (i.e. giant vs. super- or mega-giant) of the reservoir matters. Given that the discovery of a giant oil field signals a substantial increase in the country's oil reserves and thus its wealth and future production capacity and given the distribution of giant oil discoveries across countries as well as over time, each incident can be treated as a country-specific reserves shock.

Another attractive feature is that the timing of a giant oil discovery is arguably exogenous and unanticipated due to the uncertainty surrounding oil and gas exploration. While one may argue that discoveries are more likely in geographical regions with larger known and unknown endowments than others or a history of discoveries, the exact timing of a discovery is unlikely to be predictable, especially for giant oil and gas fields. Moreover, past discoveries have two opposing effects on the probability of current and future discoveries. On the one hand, assuming that more easily accessible locations are probed first, cumulative discoveries raise the cost of future successful drilling, as in the theoretical model of Pindyck (1978). On the other hand, knowledge about the territory's geology and the reservoirs' location might render future discoveries more likely ${ }^{3}$ As a result, past discoveries do not necessarily increase the probability of or reduce the uncertainty about the timing of a giant oil field discovery (compare Aretzki et al., 2017).

Since the timing of each discovery has been independently verified and documented based on multiple sources, which are reported systematically for each incident, Horn's (2014) data set is also immune to concerns about accidental or deliberate manipulation of the announcement date of a giant oil field discovery, for example by the government.

\subsection{Oil production}

For country-level petroleum production, I compile data from British Petroleum's (BP) Statistical Review of World Energy and the U.S. Energy Information Administration's (EIA) Monthly Energy Review in thousand barrels per day (tbpd) for a total of 80 countries starting in 1965.4 Each oil-producing country is treated as an independent unit of observation, except for former members of the Union of Soviet Socialist Republics (USSR), which are combined in a synthetic "Former Soviet Union" after its dissolution, both in the field discovery and oil production data.

\footnotetext{
3 In Hamilton and Atkinson (2013), for example, finding a resource today raises the cost of future discoveries, whereas extracting resources yields knowledge that reduces the cost of future discoveries.

$\square_{\mathrm{BP}}$ production data includes crude oil, tight oil, oil sands, and NGLs (the liquid content of natural gas where this is recovered separately) and excludes liquid fuels from other sources such as biomass and derivatives of coal and natural gas. EIA production data are for crude oil and lease condensate, excluding natural gas plant liquids.
} 
Hence, my analysis is based on an unbalanced panel of oil production data for 80 countries, 41 of which experienced at least one giant oil field discovery since 1945.5 All members of the "Former Soviet Union" experienced a total of 80 giant oil field discoveries since 1945. The panel includes 14 current OPEC members, all of which experienced at least one giant oil field discovery since 1945, ranging from exactly one for Gabon to 47 for Saudi Arabia. ${ }^{6}$ Table 1 reports the summary statistics for country-level petroleum production data.

\subsection{Oil consumption}

For country-level petroleum consumption, I compile data from BP's Statistical Review of World Energy and the EIA's Monthly Energy Review in thousand barrels per day (tbpd) for a total of 172 countries starting in 1965, 41 of which experienced at least one giant oil field discovery since 1945.7 In line with the treatment of oil production and discovery data, the consumption of former USSR member states is added together in a synthetic "Former Soviet Union". Given that I can draw on an even broader (unbalanced) panel when analyzing the response of domestic petroleum consumption, at each point in time, there exists a large control group of countries that has not experienced a giant oil field discovery in the recent past or the entire sample period. In fact, the latter applies to most countries in the sample. Table 2 reports the summary statistics for country-level petroleum production data.

\section{Econometric Methodology}

Inspired by Aretzki et al. (2017), I use a dynamic panel distributed lag regression (DLR) model in order to estimate the response of petroleum-producing countries to a giant oil field discovery:

$$
\Delta y_{i t}=\mathbf{A}(L) \Delta y_{i t}+\mathbf{B}(L) d_{i t}+\alpha_{i}+\mu_{t}+\epsilon_{i t},
$$

where $\Delta y_{i t}$ denotes the change in the level of oil production or consumption in tbpd in country $i$ in year $t, \alpha_{i}$ controls for country fixed effects such as geographical location or political system, for example, and $\mu_{t}$ controls for time fixed effects such as fluctuations in global crude oil demand, for example. $d_{i t}$ denotes the cumulated volume of newly discovered giant oil fields in country $i$ in year $t$ in million barrels of oil equivalents (mmboe), while $\epsilon_{i t}$ is a country-year-specific error

\footnotetext{
5 Note that the relevant sample period for oil discovery data starts in $1965-q=1945$ rather than in 1965 .

6 The list of current OPEC countries includes the five founding members Iran, Iraq, Kuwait, Saudi Arabia, and Venezuela, as well as Qatar (since 1961), Indonesia (1962-2009 and since 2016), Libya (since 1962), United Arab Emirates (since 1967), Algeria (since 1969), Nigeria (since 1971), Ecuador (1973-1992 and since 2007), Gabon (1975-1995 and since 2016), and Angola (since 2007). In what follows, these countries will be treated as OPEC members throughout, as their membership status extends over the majority of the sample period, 1965-2010, with the exception of Angola and Gabon.

$7 \mathrm{BP}$ consumption data includes inland demand, international aviation and marine bunkers, refinery fuel and loss as well as consumption of biogasoline (such as ethanol), biodiesel, and derivatives of coal and natural gas.
} 
term. $\mathbf{A}(L)$ and $\mathbf{B}(L)$ are $p$ th and $q$ th order lag polynomials with $p \geq 1$ and $q \geq 0$, respectively. In order to fully trace out the impulse response functions over a horizon of 20 years, I set $p=1$ and $q=20$ in the benchmark regression analysis.

Regarding the dynamic panel DLR model in (1), a few clarifying comments are in order. First, given that the presence of a unit root in production and consumption cannot be rejected at conventional significance levels for the vast majority of countries, I consider first differences of the dependent variable 8 Second, I do not logarithmize either the dependent variables or the volume of newly discovered petroleum in giant oil fields, because both series contain "true zeros" rather than missing values. Third, the fact that $y_{i t}$ is expressed in tbpd while $d_{i t}$ is expressed in mmboe facilitates computing the expected duration until a discrete increase in the reserves base is offset by higher production from newly discovered oil fields or existing reservoirs $9^{9}$ Fourth, Horn's (2014) data set reports three hydrocarbon volumes for each discovery: the estimated ultimate recovery (EUR), the estimated ultimate recovery of oil (EURO), and reserves (RSVS), all in mmboe, where EUR $\geq$ EURO $\geq$ RSVS. Given my interest in the response of country-level oil production and consumption, respectively, I use the EURO as a measure of the absolute size of a giant oil field discovery in what follows. Note that the EURO represents an estimate at the time of the discovery rather than a potentially revised estimate at a later date.

The panel structure of the data allows identifying the impulse responses of petroleum production and consumption to a giant oil field discovery while simultaneously controlling for country and year fixed effects. Assuming that their timing is exogenous to changes in country-specific production and consumption levels (after controlling for country and year fixed effects), giant oil discoveries correspond to quasi-natural experiments. Country $i$ belongs to the treatment group, if an oil field has been discovered on its territory in period $t$, whereas all countries without a discovery on their territories in period $t$ belong to the control group. At each point in time, we can therefore draw on a large group of countries that have not been treated. The dynamic panel specification in (1) also accommodates the fact that a country might have discovered a giant oil field on its territory in period $t-l, 1 \leq l \leq q$. Accordingly, identification does not rely on a structural vector-autoregressive model with more or less arbitrary identifying restrictions.

Due to the infrequent incident of a giant oil discovery, the high adjustment costs in petroleum

\footnotetext{
8 At the $10 \%$ level or better, the null hypothesis of a unit root in country-level production is rejected in favor of a trend-stationary alternative in 14 out of 80 or $17.5 \%$ of all cases (see Table 3). The null hypothesis of a unit root in country-level consumption is rejected in 20 out of 172 or $11.6 \%$ of all cases (see Table 4 ). It is important to note that the standard caveats about the power of unit root tests in finite samples apply also in this case.

9 In contrast to Aretzki et al. (2017), there is no need to derive the net present value of a giant oil field discovery, given that I am only interested in the quantitative response of crude oil production or consumption to an exactly quantifiable discovery. Rather than applying country-specific risk-adjusted discount rates and imposing a certain production profile from the newly found reservoir, the present paper investigates the actual response of petroleum production and consumption at the country level.
} 
production (see, e.g., Hamilton, 2009, Kilian, 2009, Güntner, 2014), and the gestation lag before a new reservoir can come on line, it is crucial to draw on a sufficiently long and broad panel. By including the autoregressive term $\mathbf{A}(L)$ in the panel DLR model in (1), I control for potential serial correlation of changes in country-level production or consumption and am able to construct impulse response functions beyond a forecast horizon of $q$ years according to

$$
\Phi(L)=\frac{\mathbf{B}(L)}{1-\mathbf{A}(L)} .
$$

\subsection{The response of OPEC producers}

In order to investigate whether a country's OPEC membership has any influence on its response to a giant oil field discovery, I introduce an additional regressor in (1) that interacts the dummy variable opec $_{i} \in\{0,1\}$ with $d_{i t}$, while again controlling for country and year fixed effects:

$$
\Delta y_{i t}=\mathbf{A}(L) \Delta y_{i t}+\mathbf{B}(L) d_{i t}+\mathbf{C}(L) d_{i t} \cdot \text { opec }_{i}+\alpha_{i}+\mu_{t}+\epsilon_{i t},
$$

where $\mathbf{C}(L)$ is a $q$ th order lag polynomials with $q \geq 0$ and $\epsilon_{i t}$ a country-year-specific error term. opec $_{i}=1$ for the 14 OPEC member countries in my panel and opec $_{i}=0$ else. As argued above, I do not account for the fact that Indonesia, Ecuador, and Gabon temporarily suspended their OPEC memberships during the sample period, while Angola joined only in 2007. If anything, this should bias any differences in results between the two groups towards zero.

From equation (3), I compute the impulse response functions of production or consumption in non-OPEC countries as in (2) and the response of OPEC countries according to

$$
\Phi_{\text {opec }}(L)=\frac{\mathbf{B}(L)+\mathbf{C}(L)}{1-\mathbf{A}(L)},
$$

where $\mathbf{C}(L) /[1-\mathbf{A}(L)]$ is the marginal impulse response of petroleum production or consumption in OPEC member countries to a giant oil field discovery of one mmboe in terms of EURO.

\subsection{Onshore vs. offshore discoveries}

Due to the likely difference in gestation lags, in an extension of (1), we also allow for differential responses to onshore and offshore oil field discoveries (compare Aretzki et al., 2017):

$$
\Delta y_{i t}=\mathbf{A}(L) \Delta y_{i t}+\mathbf{B}(L) d_{i t}^{o n}+\mathbf{C}(L) d_{i t}^{o f f}+\alpha_{i}+\mu_{t}+\epsilon_{i t}
$$

where $d_{i t}^{o n}$ and $d_{i t}^{o f f}$ denotes the EURO of newly discovered giant oil fields onshore and offshore, respectively, in country $i$ and year $t$. Note that the specification in (5) accommodates multiple discoveries in different locations in a given country and year, weighting them by their respective 
EURO in mmboe ${ }^{10}$ In equation (3), instead, each country either is an OPEC member or not.

From equation (5), it is straightforward to compute the impulse responses of country-level production or consumption to an onshore and offshore discovery of one mmboe of EURO as

$$
\Phi_{o n}(L)=\frac{\mathbf{B}(L)}{1-\mathbf{A}(L)} \quad \text { and } \quad \Phi_{o f f}(L)=\frac{\mathbf{C}(L)}{1-\mathbf{A}(L)}
$$

respectively.

\subsection{Does field size matter?}

As a final extension, I Investigate whether oil producers respond differently to the discovery of a giant as opposed to the discovery of a super- or mega-giant oil field, defined as an oil field with EURO $\geq 3$ billion boe (i.e. EURO $\geq 3,000 \mathrm{mmboe}$ ) at the time of discovery. For this purpose, I distinguish oil discoveries according to these categories in the dynamic panel DLR model:

$$
\Delta y_{i t}=\mathbf{A}(L) \Delta y_{i t}+\mathbf{B}(L) d_{i t}^{g}+\mathbf{C}(L) d_{i t}^{s g}+\alpha_{i}+\mu_{t}+\epsilon_{i t},
$$

where $d_{i t}^{g}$ and $d_{i t}^{s g}$ denotes the EURO of newly discovered giant and super- or mega-giant fields, respectively, in country $i$ and year $t$. Similar to (5), the specification in (7) accommodates the simultaneous discovery of one (or multiple) giant and super- or mega-giant oil fields in a given country and year, weighting them by their respective EURO in mmboe.

The corresponding impulse responses of country-level production or consumption to a giant and super- or mega-giant discovery of one mmboe of EURO can then be computed as

$$
\Phi_{g}(L)=\frac{\mathbf{B}(L)}{1-\mathbf{A}(L)} \quad \text { and } \quad \Phi_{s g}(L)=\frac{\mathbf{C}(L)}{1-\mathbf{A}(L)}
$$

respectively.

\section{Empirical Results}

The key question of this paper is how country-level petroleum production responds to a giant oil field discovery. While newly found reservoirs cannot be tapped without a substantial gestation lag, production at the country level might nevertheless adjust in response to a reserves discovery, even in the presence of nontrivial adjustment costs. Aretzki et al. (2017) dismiss this concern by showing that their main results are robust to removing the world's ten largest oil or gas exporters from the sample. Here, I analyze whether and how fast a country's petroleum production adjusts in response to a giant oil field discovery, and whether the associated impulse response function depends on the country's OPEC member status or the field's size and location.

10 For example, Saudi Arabia discovered four giant onshore fields (Jawb, Lughfah, Samin, and Dhib) and one giant offshore field (Hamur) in 1979 but not a single field in 1980 and 1981. 
In a second step, I consider the response of petroleum consumption to investigate whether any adjustment in country-level production is consumed within the country or exported to raise national income from resource extraction, in line with the narrative in Aretzki et al. (2017).

\subsection{The response of oil production}

Figure 2 plots the cumulated impulse response function of $\Delta y_{i t}$ to a giant oil field discovery for all countries in the panel based on the DLR model in (1). Hence, this corresponds to the average response of country-level petroleum production in tbpd to a discovery of one mmboe of EURO 11 The broken and dotted lines indicate one- and two-standard-error bootstrap confidence intervals based on the heteroskedasticity- and autocorrelation- (HAC-)robust covariance matrix in Newey and West (1987).

In response to a giant oil discovery, petroleum production in the treatment group increases within the same year and continues to rise over the subsequent four years relative to production in the control group. The corresponding impulse response function is statistically significant at an approximate $5 \%$ level for the first 1-3 years, depending on the lag order $p$. Given a plausible gestation lag of several years between discovery and the start of production from a new oil field, this finding strongly suggests that producers raise their output from existing fields in response to a boost of reserves - exactly the type of behavior dismissed by Aretzki et al. (2017).

Six years after the discovery, petroleum production in the treatment group has increased by 0.04 tbpd per mmboe of EURO relative to the control group, corresponding to an increase of 94 and 32 tbpd for a giant oil field of average and median EURO, respectively. While seemingly small, the former rivals the production level of Italy in the 1990s. The difference becomes even more pronounced about seven years after the discovery, peaking at an additional 0.08 tbpd per mmboe of EURO after 13 years. At this horizon, the relative increase in petroleum production is highly statistically significant, independent of the lag order $p$.

To put the response of country-level production into quantitative perspective, we can also compute the hypothetical lifetime until exhaustion of the newly discovered reserves. Assuming an average increase of 0.08 tbpd or $365 \cdot 0.08=29.2$ tbpy per mmboe of EURO, the discovered reserves would last for about 34.25 years. Given that I abstract from any type of heterogeneity, such as in field size and location, this figure should be taken with a grain of salt.

On the one hand, my results for the full panel confirm the common wisdom of a substantial gestation lag before a newly discovered reservoir comes on line. On the other hand, I find strong evidence that country-level production increases before a discovered oil field has been tapped,

\footnotetext{
${ }_{11}^{11}$ Recall that the mean and median EURO of giant oil field discoveries in Horn (2014) is equal to 2,348 mmboe and 800 mmboe, respectively.
} 
indicating that producers raise extraction rates from existing reservoirs in order to exploit any remaining spare capacity. In contrast to a demand-driven change in the real price of crude oil, which is of uncertain persistence, a giant oil discovery signals a substantial increase in reserves and production capacity in the near future. For this reason, high adjustment costs in petroleum production (see, e.g., Hamilton, 2009; Kilian, 2009) might be less of a deterrent over a horizon of several years. Accordingly, the above finding complements rather than competes with the finding of a near-zero short-run price elasticity of supply in Güntner (2014).

\subsection{The response of OPEC producers}

An obvious candidate for heterogeneity in the production response to a giant oil field discovery is the country's OPEC membership. Of the 590 oil fields listed in Horn's (2014) data set, 251 are located on current OPEC territories. In this section, I therefore investigate whether OPEC membership has any influence on the response to a discovery of one mmboe of EURO.

The upper panels of Figure 3 plot the cumulated impulse responses of OPEC production, while the lower panels plot the cumulated impulse responses of non-OPEC production based on the extended DLR model in (3) for $p=1$ and $p=4$, respectively. The broken and dotted lines indicate one- and two-standard-error bootstrap confidence intervals based on the HAC-robust covariance matrix in Newey and West (1987).

Figure 3 reveals both qualitative and quantitative heterogeneity in the production responses to a giant oil field discovery. While, on average over the sample period, non-OPEC production increases significantly already during the first five years, OPEC production barely responds until about seven years after the discovery. Moreover, while production of treated OPEC members peaks at +0.08 tbpd after 13 years, that of non-OPEC producers is up by the same amount within four years and peaks at +0.11 tbpd after 18 years relative to the control group. Finally, while the response of non-OPEC production is statistically significant at an approximate $5 \%$ level throughout, the response of OPEC production is only significant (at the $5 \%$ level) between nine and 15 years after the discovery. Note that these findings are robust to the lag order $p$.

There are several candidate interpretations for the different response of OPEC producers to giant oil field discoveries. Adherents of the popular theory of OPEC as an effective cartel might argue that its members refrain from producing out of newly discovered reserves or - using the language of Peterson (1978) — "over-conserve the resource" in order to stabilize the price of oil. However, this seems inconsistent with the observation that the impulse response function of OPEC production is (at least partially) statistically significant after about 10 years. Similarly, members of OPEC might postpone production to conserve newly discovered oil reserves, which represent the main or only source of government revenue in these countries. Instead, the delayed 
response might also be due to the fact that OPEC producers operated at or close to full capacity during large parts of the sample period. If this was the case, then OPEC production could not respond until a newly discovered oil reservoir has come on line. Very likely, the heterogeneity in Figure 3 arises from a combination of the above reasons.

\subsection{Onshore vs. offshore discoveries}

Aretzki et al. (2017) report qualitative differences in the responses of consumption, saving/GDP, investment/GDP, and employment to giant onshore and offshore discoveries. In this section, I therefore investigate whether the documented heterogeneity with respect to field location carries over to the impulse response functions of country-level petroleum production.

The upper panels of Figure 4 plot the cumulated impulse responses to a giant onshore oil field discovery, while the lower panels plot the cumulated impulse responses to a giant offshore oil field discovery based on the extended DLR model in (5) for $p=1$ and $p=4$, respectively. The broken and dotted lines indicate HAC-robust one- and two-standard-error confidence intervals.

The upper panels suggest that, in response to an onshore discovery, country-level production increases on impact, while the impulse response function is not statistically different from zero at an approximate $5 \%$ level for the rest of the 20-year horizon. Relative to the control group, production of the treated countries increases by less than six tbpd per mmboe of EURO.

Instead, the lower panels indicate that country-level production does not respond on impact but becomes increasingly positive and statistically significant from about four years after a giant offshore discovery. It is important to note that the impulse response function peaks at +0.17 tbpd per mmboe of EURO relative to the control group after 16 years, i.e. three times the amount for an onshore discovery. The differences are statistically significant at an approximate $32 \%$ level and robust to the lag order $p$.

Of the 590 giant oil field discoveries in Horn's (2014) data, 394 (66.8\%) are located onshore. The remaining 196 offshore discoveries $(33.2 \%)$ account for the significant increase in petroleum production relative to the control group. One might thus argue that field location is correlated with ownership, explaining the similarity between response patterns for OPEC and non-OPEC countries in Figure 3 with that for onshore and offshore discoveries, respectively, in Figure 4 Indeed, of the 251 giant oil fields discovered by OPEC members, $70(27.9 \%)$ are located offshore, while $126(37.2 \%)$ of the 339 oil fields discovered on non-OPEC territories are located offshore. Hence, the larger propensity to produce out of offshore reservoirs seems to be linked to the fact that a larger fraction of giant oil fields discovered offshore are located on non-OPEC territories and thus more likely to be used either directly or by raising production from existing fields. 


\subsection{Does field size matter?}

While, in the previous analysis, each discovery is quantified by its EURO, Horn's (2014) data set also classifies the respective oil field as a "giant" (89.7\%), "super-giant" (9.8\%), or "mega-giant" $(0.5 \%)$. In what follows, I therefore investigate whether oil production responds differently to the discovery of a giant as opposed to the discovery of a super- or mega-giant, roughly defined as an oil field with an EURO $\geq 3$ billion boe (i.e. EURO $\geq 3,000 \mathrm{mmboe}$ ) at the time of discovery.

The upper panels of Figure 5 plot the cumulated impulse responses to a giant oil discovery, while the lower panels plot the cumulated impulse responses to a super- or mega-giant oil field discovery based on the extended DLR model in (7) for $p=1$ and $p=4$, respectively, where broken and dotted lines indicate HAC-robust one- and two-standard-error confidence intervals.

Surprisingly, the discovery of an "ordinary" giant oil field does not trigger a statistically significant increase in petroleum production relative to the control group, except for a partially significant increase between one and three years after the discovery. This finding is robust to the lag order of the DLR model.

Considering now the lower panels, the discovery of an exceptionally large "super-" or "megagiant" oil field seems to raise petroleum production in the treatment group by up to 0.09 tbpd per mmboe of EURO after 13 years. This increase is robust to the DLR lag order and significant at an approximate $5 \%$ level between six and 16 respectively nine and 13 years after the discovery.

Our results suggest that the discovery of an ordinary giant oil field induces producers to extract more from existing reservoirs shortly after the event, whereas the discovery of an exceptionally large super- or mega-giant oil field, such as the Saudi Arabian Ghawar, triggers a delayed and persistent increase in production levels. It is important to note that a field's EURO is as of the time of its discovery. Hence, the above findings seem to reflect effective differences in the countries' production decision conditional on the size of a newly discovered giant oil field. Apparently, field size matters.

\subsection{The response of oil consumption}

In this section, I investigate whether the increase in petroleum production in Figure 2 is accompanied by an equally sized increase in domestic consumption or rather destined for raising (net) exports. Ideally, I would like to use a direct measure of net exports as the dependent variable. However, missing data on crude oil inventories above the ground for most countries implies that

$$
\{\text { net exports }\}_{t}=\{\text { production }\}_{t}-\{\text { consumption }\}_{t}-\Delta\{\text { inventories }\}_{t}
$$

contains an unknown variable on the right-hand side. 
For this reason, I substitute petroleum consumption for petroleum production in the DLR models in (1) and (3). The availability of annual consumption data starting in 1965 for a total of 172 countries implies that we can draw on an even larger control group of countries without a giant oil field discovery on their territory at each point in time.

Figure 6 plots the cumulated impulse response function of $\Delta y_{i t}$ to a giant oil field discovery for all countries in the panel based on the DLR model in (1), corresponding to the average response of country-level petroleum consumption in tbpd to a discovery of one mmboe of EURO. As before, the broken and dotted lines indicate one- and two-standard-error HAC-robust bootstrap confidence intervals. In response to a giant oil discovery, petroleum consumption in the treatment group hardly responds on impact. From period one onwards, the level of consumption starts to rise relative to the control group, peaking at a cumulated +0.025 and +0.045 tbpd after ten to twelve years for $p=1$ and $p=4$, respectively. While the impulse response function is partially significant at an approximate $32 \%$ level for $p=1$, it is statistically significant at the $5 \%$ level for $p=4$ around five years after the discovery.

A comparison of Figures 2 and 6 reveals that domestic petroleum consumption increases by less than domestic production. Although the differences in the corresponding impulse response functions are not statistically significant, my findings suggest that at least part of the increase in production raises either the country's net oil exports or crude oil inventories above the ground. Given that the difference between petroleum production and consumption persist over a horizon of 20 years, a giant oil field discovery eventually translates into higher net exports ${ }^{12}$

Now consider Figure 7, which plots the impulse response functions of cumulated changes in OPEC and non-OPEC consumption after a giant oil field discovery based on the DLR model in (3), where broken and dotted lines indicate one- and two-standard-error HAC-robust bootstrap confidence intervals. While the upper-right panel suggests that, for $p=1$, an initial increase of petroleum consumption in OPEC member states is followed by a persistent decrease over the remaining forecast horizon that is statistically significant at the $5 \%$ level after twelve years, the response for $p=4$ in the upper-left panel seems to be virtually flat. In contrast, the lower panels of Figure 7 show that petroleum consumption in non-OPEC countries increases in response to a giant oil field discovery, peaking at +0.07 tbpd after twelve years. The latter impulse response functions are statistically significant at an approximate 5\% level between three and 13 years after the discovery and robust to the lag order $p$.

It is important to note that the difference between the impulse response functions of OPEC

\footnotetext{
${ }_{12}^{12}$ Note that the cumulated impulse response functions in Figures 2 and 6 correspond to flow variables, whereas crude oil inventories are a stock variable. A persistent difference between petroleum production and consumption must therefore translate into a continuous increase in crude oil inventories in response to a giant oil field discovery.
} 
and non-OPEC consumption are statistically significant at the 5\% (32\%) level between ten and 13 years after the discovery for $p=1(p=4)$. Accordingly, the increase of petroleum production in the treated group relative to the control group in Figure 6 is driven by non-OPEC countries, whereas the level of consumption in OPEC member states remains constant or even decreases.

\section{Conclusion}

In this paper, I investigate how domestic petroleum production and consumption respond to a sizeable increase in a country's resource base. The use of a comprehensive data set of giant oil field discoveries with arguable exogenous timing facilitates analyzing the endogenous behavior of oil producers in a quasi-natural experiment. By using an unbalanced panel of oil production and consumption data starting in 1965 for 80 and 172 countries, respectively, many of which have never experienced a giant oil field discovery, I can control for country and year fixed effects. Hence, each impulse response function corresponds to the difference between a country treated with a giant oil discovery in the recent past and all countries in the control group.

I find that country-level production starts to increase before the newly discovered field has come on line, indicating that the reserves discovery spurs production from existing reservoirs in the presence of spare capacity. When distinguishing between OPEC and non-OPEC producers, I find that the response of the former is delayed relative to the response of the latter, while both groups raise their production levels over the subsequent twenty years following a giant oil field discovery. This increase in production seems to arise mainly from offshore rather than onshore discoveries, which are relatively more concentrated on non-OPEC territories, and from "super-" and "mega-giant" rather than ordinary "giant" fields.

Finally, I show that country-level petroleum consumption also increases in response to a giant oil field discovery - albeit by quantitatively less and statistically less significantly. Depending on the specification of the panel distributed lag regression model, OPEC consumption decreases whereas non-OPEC consumption increases significantly in response to a giant oil field discovery, suggesting that the increase in reserves might be devoted to different aims in the two groups.

These findings shed light on the actual response of country-level petroleum production to a giant oil field discovery rather than imposing a certain production profile and dismissing the possibility of adjusting extraction rates from existing reservoirs, as in Aretzki et al. (2017). By comparing the impulse response functions of country-level production and consumption, I can comment on the likely use of increased domestic petroleum supply. However, a more rigorous analysis of the effects of a giant oil discovery on the current account requires panel data on (net) oil exports or inventories. Due to the current lack of such data, this is left for future research. 


\section{Acknowledgements}

I would like to thank Christiane Baumeister and Yuriy Gorodnichenko for helpful comments. The research on this topic was conducted while the author visited the University of California at Berkeley and Ludwig-Maximilians-Universität Munich as a Postdoctoral Researchers International Mobility Experience (P.R.I.M.E.) Fellow of the German Academic Exchange Service (DAAD). Financial support by the DAAD and the European Union is gratefully acknowledged.

\section{References}

Aretzki, R., V. A. Ramey, and L. Sheng (2017). News shocks in open economies: Evidence from giant oil discoveries. Quarterly Journal of Economics 132(1), 103-155.

Arrow, K. J. and S. Chang (1982). Optimal pricing, use, and exploration of uncertain natural resource stocks. Journal of Environmental Economics and Management 9, 1-10.

Black, G. and J. T. LaFrance (1998). Is Hotelling's rule relevant to domestic oil production? Journal of Environmental Economics and Management 36, 149-169.

Farrow, S. (1985). Testing the efficiency of extraction from a stock resource. Journal of Political Economy 93(3), 452-487.

Farzin, Y. H. (2001). The impact of oil price on additions to US proven reserves. Resource and Energy Economics 23, 271-291.

Güntner, J. H. F. (2014). How do oil producers respond to oil demand shocks? Energy Economics 44, 1-13.

Hamilton, J. D. (2009). Causes and consequences of the oil shock of 2007-08. Brookings Papers on Economic Activity 40(1), 215-283.

Hamilton, K. and G. Atkinson (2013). Resource discoveries, learning, and national income accounting. World Bank Policy Reserach Working Paper 6505 (available at SSRN: https://ssrn.com/abstract=2285342).

Harding, T., R. Stefanski, and G. Toews (2016). Boom goes the price: Giant resource discoveries and real exchange rate appreciation. School of Economics and Finance Discussion Paper 1608 (available at https://research-repository.st-andrews.ac.uk/handle/10023/8864).

Höök, M., R. Hirsch, and K. Aleklett (2009). Giant oil field decline rates and their influence on world oil production. Energy Policy 37(6), 2262-2272. 
Hotelling, H. (1931). The economics of exhaustible resources. Journal of Political Economy 39(2), 137-175.

Kilian, L. (2009). Not all oil price shocks are alike: Disentangling demand and supply shocks in the crude oil market. American Economic Review 99(3), 1053-1069.

Lepore, J. J. and M. Rastad (2011). Do oil producers extract more as they become richer? A natural experiment using unanticipated reserve discoveries. Working Paper (available at SSRN: http://dx.doi.org/10.2139/ssrn.1927652).

Litzenberger, R. H. and N. Rabinowitz (1995). Backwardation in oil futures markets: Theory and empirical evidence. Journal of Finance 50(5), 1517-1545.

Mohn, K. and P. Osmundsen (2008). Exploration economics in a regulated petroleum province: The case of the Norwegian Continental Shelf. Energy Economics 30, 303-320.

Newey, W. K. and K. D. West (1987). A simple, positive semi-definite, heteroskedasticity and autocorrelation consistent covariance matrix. Econometrica 55(3), 703-708.

Pesaran, H. M. (1990). An econometric analysis of exploration and extraction of oil in the U.K. Continental Shelf. The Economic Journal 100(401), 367-390.

Peterson, F. M. (1978). A model of mining and exploring for exhaustible resources. Journal of Environmental Economics and Management 5, 236-251.

Pickering, A. (2008). The oil reserves production relationship. Energy Economics 30, 352-370.

Pindyck, R. S. (1978). The optimal exploration and production of nonrenewable resources. Journal of Political Economy 86(5), 841-861.

Pindyck, R. S. (1980). Uncertainty and exhaustible resource markets. Journal of Political Economy 88(6), 1203-1225.

Spiro, D. (2014). Resource prices and planning horizons. Journal of Economic Dynamics and Control 48, 159-175.

Thompson, A. C. (2001). The Hotelling principle, backwardation of futures prices and the values of developed petroleum reserves - the production constraint hypothesis. Resource and Energy Economics 23, 133-156.

Tsui, K. K. (2009). More oil, less democracy: Evidence from worldwide crude oil discoveries. The Economic Journal 121, 89-115. 


\section{Tables and Figures}

Table 1: Summary statistics of country-level petroleum production data (in tbpd)

\begin{tabular}{|c|c|c|c|c|}
\hline Country & Sample mean & Standard deviation & Maximum & Minimum \\
\hline Albania & 22.931 & 20.928 & 5.4 & 75.0 \\
\hline Algeria & 1328.348 & 338.323 & 577.4 & 1992.3 \\
\hline Angola & 634.793 & 608.857 & 10.9 & 1900.9 \\
\hline Argentina & 593.970 & 187.974 & 275.7 & 910.4 \\
\hline Australia & 490.396 & 193.778 & 7.0 & 818.8 \\
\hline Austria & 26.823 & 1.785 & 23.2 & 30.5 \\
\hline Bahrain & 51.148 & 4.180 & 43.9 & 63.9 \\
\hline Bangladesh & 3.200 & 2.448 & 0.2 & 6.9 \\
\hline Belgium & 10.598 & 1.850 & 5.6 & 13.1 \\
\hline Bolivia & 40.322 & 13.850 & 23.3 & 67.4 \\
\hline Brazil & 841.890 & 718.118 & 96.0 & 2346.3 \\
\hline Brunei & 174.275 & 37.676 & 80.0 & 261.0 \\
\hline Bulgaria & 2.536 & 1.450 & 0.0 & 6.0 \\
\hline Cameroon & 106.830 & 38.501 & 58.0 & 185.0 \\
\hline Canada & 2264.095 & 798.754 & 920.0 & 4292.3 \\
\hline Chad & 117.020 & 42.148 & 23.6 & 173.4 \\
\hline Chile & 27.446 & 13.543 & 10.9 & 54.0 \\
\hline China & 2520.111 & 1174.292 & 227.1 & 4246.0 \\
\hline Colombia & 426.212 & 261.219 & 129.0 & 1004.0 \\
\hline Congo (Brazzaville) & 144.244 & 100.699 & 0.3 & 302.3 \\
\hline Congo (Kinshasa) & 24.760 & 4.332 & 19.7 & 33.0 \\
\hline Ivory Coast & 22.954 & 18.118 & 0.8 & 63.3 \\
\hline Cuba & 32.907 & 17.703 & 6.0 & 59.2 \\
\hline Denmark & 162.931 & 129.806 & 2.0 & 390.0 \\
\hline Ecuador & 297.511 & 169.427 & 4.0 & 556.4 \\
\hline Egypt & 626.590 & 267.580 & 108.6 & 940.7 \\
\hline Equatorial Guinea & 187.004 & 135.951 & 0.1 & 358.0 \\
\hline Finland & 7.931 & 3.160 & 0.8 & 15.3 \\
\hline Former Yugoslavia & 62.358 & 18.370 & 39.0 & 90.0 \\
\hline France & 93.043 & 16.217 & 61.4 & 119.3 \\
\hline Gabon & 217.381 & 82.641 & 25.3 & 364.5 \\
\hline Germany & 146.846 & 15.901 & 108.5 & 193.2 \\
\hline Ghana & 13.918 & 28.332 & 0.0 & 105.9 \\
\hline Greece & 13.125 & 8.341 & 1.0 & 31.0 \\
\hline Guatemala & 12.158 & 6.961 & 3.0 & 23.7 \\
\hline Hungary & 49.484 & 12.524 & 25.3 & 68.1 \\
\hline India & 536.274 & 284.729 & 62.3 & 916.1 \\
\hline Indonesia & 1243.859 & 343.275 & 474.0 & 1685.0 \\
\hline Iran & 3646.285 & 1146.691 & 1321.0 & 6060.3 \\
\hline Iraq & 1884.866 & 810.909 & 285.4 & 3488.6 \\
\hline Israel & 5.128 & 7.925 & 0.1 & 36.0 \\
\hline Italy & 75.137 & 37.305 & 23.4 & 126.8 \\
\hline Japan & 94.900 & 35.467 & 38.0 & 142.6 \\
\hline Kuwait & 2163.889 & 736.729 & 185.0 & 3339.0 \\
\hline
\end{tabular}


Table 1 - Continued from previous page

\begin{tabular}{l|cccc}
\hline Country & Sample mean & Standard deviation & Maximum & Minimum \\
\hline Libya & 1592.878 & 558.205 & 478.8 & 3357.0 \\
Malaysia & 460.743 & 278.360 & 1.0 & 776.0 \\
Mexico & 2401.182 & 1187.857 & 362.0 & 3830.2 \\
Mongolia & 4.247 & 5.877 & 0.1 & 20.8 \\
Myanmar & 18.866 & 6.609 & 8.4 & 32.0 \\
Netherlands & 86.072 & 25.184 & 30.7 & 132.3 \\
New Zealand & 43.805 & 16.230 & 9.0 & 68.2 \\
Nigeria & 1816.621 & 613.883 & 141.0 & 2509.1 \\
Norway & 1733.464 & 1173.318 & 6.0 & 3418.0 \\
Oman & 614.394 & 263.510 & 57.0 & 960.7 \\
Pakistan & 55.145 & 20.658 & 11.2 & 98.0 \\
Papua New Guinea & 57.841 & 31.586 & 0.2 & 125.9 \\
Peru & 115.024 & 39.376 & 64.0 & 196.0 \\
Philippines & 13.400 & 10.832 & 0.4 & 38.6 \\
Poland & 17.856 & 12.871 & 4.4 & 40.2 \\
Qatar & 717.063 & 498.581 & 233.0 & 1997.8 \\
Romania & 194.347 & 79.781 & 83.1 & 312.7 \\
Saudi Arabia & 7915.486 & 2730.347 & 2219.0 & 11634.5 \\
South Africa & 151.076 & 68.878 & 4.0 & 234.0 \\
Spain & 32.288 & 9.900 & 3.9 & 46.8 \\
Sudan & 213.945 & 168.631 & 2.0 & 483.1 \\
Suriname & 8.500 & 4.484 & 1.0 & 15.4 \\
Sweden & 4.349 & 4.016 & 0.1 & 12.3 \\
Syria & 320.502 & 199.414 & 21.0 & 676.7 \\
Thailand & 178.532 & 149.715 & 1.3 & 459.0 \\
Timor-Leste & 84.407 & 14.039 & 51.9 & 100.9 \\
Trinidad and Tobago & 161.625 & 28.742 & 112.0 & 230.0 \\
Tunisia & 87.125 & 20.590 & 16.2 & 118.2 \\
Turkey & 54.813 & 12.236 & 39.6 & 85.3 \\
United Arab Emirates & 2062.978 & 882.492 & 282.0 & 3711.6 \\
United Kingdom & 1543.125 & 1024.236 & 1.6 & 2930.2 \\
United States & 9180.894 & 1387.321 & 6783.7 & 11644.1 \\
Venezuela & 2802.600 & 579.976 & 1744.0 & 3754.0 \\
Vietnam & 237.896 & 135.523 & 0.8 & 423.6 \\
Yemen & 289.877 & 128.164 & 10.0 & 457.3 \\
Former Soviet Union & 10194.760 & 2596.579 & 4858.0 & 13802.0 \\
\hline & & & &
\end{tabular}

Note: The sample period is $1965-2014$. 
Table 2: Summary statistics of country-level petroleum consumption data (in tbpd)

\begin{tabular}{|c|c|c|c|c|}
\hline Country & Sample mean & Standard deviation & Maximum & Minimum \\
\hline Afghanistan & $\bar{~} 13.359$ & $\overline{12.558}$ & 2.0 & $\overline{43.0}$ \\
\hline Albania & 27.197 & 9.966 & 11.7 & 46.0 \\
\hline Algeria & 177.595 & 99.249 & 26.8 & 394.9 \\
\hline American Samoa & 3.605 & 0.553 & 2.3 & 4.6 \\
\hline Angola & 43.884 & 29.993 & 19.0 & 112.0 \\
\hline Antigua and Barbuda & 3.466 & 0.871 & 2.0 & 4.9 \\
\hline Argentina & 474.268 & 62.966 & 388.1 & 669.5 \\
\hline Aruba & 5.383 & 1.886 & 0.7 & 7.7 \\
\hline Australia & 715.558 & 177.971 & 346.3 & 1028.6 \\
\hline Austria & 228.181 & 42.708 & 107.1 & 291.7 \\
\hline The Bahamas & 21.691 & 4.685 & 14.6 & 30.9 \\
\hline Bahrain & 26.978 & 11.409 & 15.4 & 50.0 \\
\hline Bangladesh & 53.659 & 28.812 & 2.2 & 115.4 \\
\hline Barbados & 8.559 & 1.103 & 6.7 & 10.8 \\
\hline Belgium & 547.027 & 105.509 & 312.1 & 730.4 \\
\hline Belize & 3.312 & 1.960 & 1.1 & 7.3 \\
\hline Benin & 11.912 & 10.278 & 2.0 & 34.8 \\
\hline Bermuda & 4.093 & 0.731 & 3.2 & 6.3 \\
\hline Bolivia & 39.293 & 15.608 & 21.1 & 71.4 \\
\hline Botswana & 9.856 & 5.617 & 2.0 & 19.4 \\
\hline Brazil & 1551.522 & 752.074 & 306.8 & 3228.8 \\
\hline Brunei & 10.965 & 4.425 & 4.0 & 18.2 \\
\hline Bulgaria & 145.967 & 67.005 & 71.2 & 271.3 \\
\hline Burkina Faso & 6.478 & 3.322 & 2.9 & 13.4 \\
\hline Myanmar & 25.891 & 8.364 & 15.2 & 43.0 \\
\hline Cambodia & 14.420 & 11.901 & 1.9 & 34.3 \\
\hline Cameroon & 24.584 & 5.992 & 16.0 & 38.7 \\
\hline Canada & 1845.202 & 346.809 & 1108.1 & 2404.5 \\
\hline Cape Verde & 1.391 & 0.752 & 0.4 & 2.6 \\
\hline Cayman Islands & 2.273 & 1.071 & 0.7 & 4.5 \\
\hline Central African Republic & 1.925 & 0.383 & 1.0 & 2.5 \\
\hline Chad & 1.560 & 0.378 & 0.9 & 2.4 \\
\hline Chile & 180.112 & 96.751 & 68.1 & 371.6 \\
\hline China & 3661.067 & 3101.135 & 216.1 & 11056.5 \\
\hline Colombia & 198.858 & 60.316 & 83.8 & 309.6 \\
\hline Congo (Brazzaville) & 7.148 & 3.388 & 4.0 & 16.6 \\
\hline Congo (Kinshasa) & 17.723 & 4.819 & 8.1 & 25.4 \\
\hline Costa Rica & 31.385 & 13.122 & 13.4 & 50.0 \\
\hline Ivory Coast & 28.424 & 3.496 & 21.7 & 37.0 \\
\hline Cuba & 194.891 & 22.336 & 141.4 & 228.5 \\
\hline Cyprus & 40.675 & 14.321 & 17.0 & 60.2 \\
\hline Czech Republic & 180.380 & 38.256 & 78.1 & 241.9 \\
\hline Denmark & 230.663 & 59.362 & 156.9 & 366.5 \\
\hline Djibouti & 9.273 & 2.434 & 4.5 & 11.8 \\
\hline Dominican Republic & 82.637 & 30.801 & 36.6 & 122.3 \\
\hline Ecuador & 103.611 & 68.630 & 13.5 & 258.8 \\
\hline Egypt & 412.113 & 210.247 & 91.7 & 813.2 \\
\hline
\end{tabular}


Table 2 - Continued from previous page

\begin{tabular}{|c|c|c|c|c|}
\hline Country & Sample mean & Standard deviation & Maximum & Minimum \\
\hline El Salvador & 29.707 & 12.868 & 11.7 & 45.5 \\
\hline Equatorial Guinea & 1.525 & 1.507 & 0.4 & 5.2 \\
\hline Eritrea & 5.089 & 1.544 & 2.7 & 7.9 \\
\hline Ethiopia & 24.942 & 12.458 & 11.6 & 52.4 \\
\hline Faroe Islands & 4.180 & 0.592 & 2.9 & 4.9 \\
\hline Fiji & 9.007 & 3.907 & 5.3 & 17.9 \\
\hline Finland & 214.111 & 28.748 & 110.8 & 260.9 \\
\hline Former Yugoslavia & 264.199 & 47.217 & 153.1 & 330.7 \\
\hline France & 1907.703 & 287.339 & 1069.8 & 2507.9 \\
\hline French Guiana & 5.013 & 1.648 & 2.2 & 7.0 \\
\hline French Polynesia & 5.560 & 1.395 & 1.5 & 7.2 \\
\hline Gabon & 14.191 & 2.540 & 9.8 & 19.0 \\
\hline Gambia & 1.830 & 0.714 & 1.1 & 3.4 \\
\hline Germany & 2688.320 & 321.967 & 1714.2 & 3341.8 \\
\hline Ghana & 33.605 & 18.207 & 13.7 & 78.0 \\
\hline Gibraltar & 20.732 & 14.894 & 2.4 & 54.0 \\
\hline Greece & 282.616 & 102.241 & 85.0 & 442.4 \\
\hline Greenland & 3.992 & 1.313 & 1.6 & 7.0 \\
\hline Guadeloupe & 11.121 & 3.509 & 3.5 & 17.0 \\
\hline Guam & 18.527 & 7.910 & 4.6 & 35.0 \\
\hline Guatemala & 47.491 & 19.825 & 23.0 & 76.1 \\
\hline Guinea & 7.698 & 1.219 & 5.3 & 9.3 \\
\hline Guinea-Bissau & 1.899 & 0.727 & 0.6 & 2.7 \\
\hline Guyana & 8.971 & 2.151 & 4.4 & 11.5 \\
\hline Haiti & 9.097 & 4.074 & 3.7 & 16.6 \\
\hline Honduras & 27.916 & 14.436 & 10.8 & 51.2 \\
\hline Hong Kong & 176.808 & 99.476 & 40.6 & 368.6 \\
\hline Hungary & 162.932 & 41.504 & 73.1 & 249.3 \\
\hline Iceland & 14.838 & 2.908 & 9.0 & 19.0 \\
\hline India & 1511.159 & 1101.585 & 252.6 & 3845.9 \\
\hline Indonesia & 730.275 & 489.367 & 114.8 & 1641.0 \\
\hline Iran & 1055.963 & 608.453 & 133.9 & 2038.4 \\
\hline Iraq & 436.025 & 151.570 & 205.0 & 750.0 \\
\hline Ireland & 118.846 & 40.541 & 46.7 & 195.0 \\
\hline Israel & 184.653 & 63.878 & 80.8 & 288.1 \\
\hline Italy & 1750.152 & 260.595 & 982.2 & 2035.8 \\
\hline Jamaica & 55.407 & 14.282 & 30.8 & 82.4 \\
\hline Japan & 4735.258 & 926.149 & 1705.1 & 5802.0 \\
\hline Jordan & 85.347 & 25.954 & 37.0 & 137.2 \\
\hline Kenya & 52.771 & 16.270 & 34.5 & 87.2 \\
\hline Kuwait & 204.242 & 141.952 & 63.5 & 505.5 \\
\hline Laos & 2.357 & 0.738 & 1.1 & 3.2 \\
\hline Lebanon & 79.189 & 31.343 & 33.0 & 128.9 \\
\hline Lesotho & 1.326 & 0.488 & 0.7 & 3.7 \\
\hline Liberia & 5.223 & 3.428 & 2.2 & 13.0 \\
\hline Libya & 192.119 & 59.758 & 100.0 & 331.2 \\
\hline Luxembourg & 43.041 & 15.014 & 21.0 & 64.8 \\
\hline Macau & 8.897 & 3.409 & 3.1 & 15.1 \\
\hline
\end{tabular}


Table 2 - Continued from previous page

\begin{tabular}{|c|c|c|c|c|}
\hline Country & Sample mean & Standard deviation & Maximum & Minimum \\
\hline Madagascar & 10.318 & 3.597 & 5.7 & 17.4 \\
\hline Malawi & 4.736 & 1.509 & 2.0 & 7.2 \\
\hline Malaysia & 339.667 & 249.401 & 46.3 & 815.2 \\
\hline Maldives & 2.939 & 2.641 & 0.1 & 7.0 \\
\hline Mali & 3.738 & 0.757 & 1.6 & 4.9 \\
\hline Malta & 18.474 & 11.700 & 6.0 & 47.1 \\
\hline Martinique & 11.447 & 4.487 & 3.9 & 16.9 \\
\hline Mauritania & 14.653 & 7.990 & 3.4 & 23.8 \\
\hline Mauritius & 15.469 & 6.762 & 5.2 & 25.1 \\
\hline Mexico & 1366.706 & 614.938 & 296.4 & 2067.3 \\
\hline Mongolia & 14.258 & 4.050 & 8.0 & 24.6 \\
\hline Morocco & 154.130 & 61.179 & 85.0 & 293.0 \\
\hline Mozambique & 10.831 & 3.633 & 6.5 & 18.1 \\
\hline Namibia & 14.914 & 5.457 & 6.9 & 22.0 \\
\hline Nepal & 10.684 & 6.755 & 2.0 & 21.9 \\
\hline Netherlands & 789.600 & 142.871 & 478.9 & 1065.1 \\
\hline Netherlands Antilles & 81.808 & 25.014 & 62.7 & 156.8 \\
\hline New Caledonia & 10.718 & 5.540 & 6.0 & 30.2 \\
\hline New Zealand & 108.063 & 30.046 & 57.2 & 154.4 \\
\hline Nicaragua & 35.219 & 62.338 & 12.1 & 280.0 \\
\hline Niger & 4.182 & 1.361 & 0.0 & 5.4 \\
\hline Nigeria & 250.319 & 35.044 & 170.0 & 311.6 \\
\hline North Korea & 42.606 & 22.422 & 13.3 & 76.5 \\
\hline Norway & 195.800 & 34.574 & 99.8 & 243.2 \\
\hline Oman & 52.441 & 36.624 & 16.0 & 163.2 \\
\hline Pakistan & 230.186 & 131.776 & 71.3 & 457.8 \\
\hline Palestinian Territories & 13.838 & 6.275 & 3.1 & 22.1 \\
\hline Panama & 76.423 & 17.106 & 35.0 & 124.9 \\
\hline Papua New Guinea & 29.379 & 49.885 & 12.0 & 226.0 \\
\hline Paraguay & 37.121 & 70.133 & 9.0 & 314.0 \\
\hline Peru & 135.174 & 35.440 & 72.4 & 231.1 \\
\hline Philippines & 241.916 & 80.809 & 84.9 & 390.0 \\
\hline Poland & 354.897 & 125.858 & 108.7 & 576.4 \\
\hline Portugal & 215.785 & 88.513 & 50.4 & 342.1 \\
\hline Puerto Rico & 167.068 & 45.324 & 20.0 & 222.8 \\
\hline Qatar & 68.393 & 59.936 & 16.6 & 200.6 \\
\hline Reunion & 216.401 & 825.432 & 4.3 & 3493.0 \\
\hline Romania & 250.502 & 63.165 & 142.5 & 387.1 \\
\hline Rwanda & 4.445 & 1.204 & 1.1 & 5.6 \\
\hline Saudi Arabia & 1269.161 & 816.450 & 366.4 & 3185.5 \\
\hline Senegal & 24.472 & 9.123 & 6.8 & 39.1 \\
\hline Seychelles & 76.224 & 293.361 & 1.1 & 1240.0 \\
\hline Sierra Leone & 10.932 & 19.083 & 3.4 & 73.2 \\
\hline Singapore & 486.996 & 364.162 & 71.5 & 1273.5 \\
\hline Slovakia & 90.080 & 25.428 & 44.9 & 139.1 \\
\hline Somalia & 111.829 & 350.465 & 3.7 & 1300.9 \\
\hline South Africa & 358.155 & 141.330 & 117.7 & 607.0 \\
\hline South Korea & 1249.441 & 950.317 & 25.0 & 2458.2 \\
\hline
\end{tabular}


Table 2 - Continued from previous page

\begin{tabular}{l|cccc}
\hline Country & Sample mean & Standard deviation & Maximum & Minimum \\
\hline Spain & 1055.532 & 359.950 & 269.1 & 1613.1 \\
Sri Lanka & 54.578 & 24.023 & 17.0 & 100.2 \\
Sudan & 45.488 & 31.724 & 4.8 & 114.8 \\
Suriname & 35.753 & 82.672 & 6.7 & 309.1 \\
Swaziland & 23.615 & 67.687 & 2.0 & 250.7 \\
Sweden & 406.041 & 80.868 & 306.3 & 569.4 \\
Switzerland & 254.145 & 25.700 & 164.8 & 298.4 \\
Syria & 209.703 & 77.110 & 12.0 & 346.6 \\
Taiwan & 576.255 & 350.459 & 43.9 & 1110.3 \\
Tanzania & 18.812 & 7.851 & 1.3 & 34.4 \\
Thailand & 530.072 & 397.403 & 47.6 & 1274.0 \\
Togo & 9.468 & 9.493 & 3.5 & 43.1 \\
Trinidad and Tobago & 34.887 & 12.405 & 16.8 & 68.3 \\
Tunisia & 77.745 & 21.534 & 51.5 & 146.3 \\
Turkey & 451.157 & 207.491 & 89.8 & 724.2 \\
Uganda & 48.990 & 161.886 & 3.2 & 694.0 \\
United Arab Emirates & 287.971 & 248.389 & 0.2 & 873.0 \\
United Kingdom & 1740.495 & 168.088 & 1448.7 & 2226.2 \\
United States & 17394.674 & 2235.350 & 11522.2 & 20802.2 \\
Uruguay & 35.793 & 13.165 & 1.0 & 60.9 \\
Venezuela & 447.367 & 174.951 & 181.5 & 825.0 \\
Vietnam & 136.771 & 112.362 & 16.3 & 405.9 \\
Virgin Islands, U.S. & 73.612 & 29.715 & 9.3 & 117.0 \\
Wake Island & 16.206 & 29.381 & 8.6 & 134.0 \\
Western Sahara & 2.485 & 4.111 & 1.1 & 19.3 \\
Yemen & 85.929 & 36.061 & 14.0 & 161.6 \\
Zambia & 12.723 & 1.421 & 10.7 & 15.8 \\
Zimbabwe & 19.094 & 5.882 & 12.0 & 31.0 \\
Former Soviet Union & 5633.537 & 1934.583 & 3314.0 & 8455.3 \\
\hline
\end{tabular}

Note: The sample period is $1965-2014$. 
Table 3: Augmented Dickey-Fuller test for a unit root in country-level petroleum production

\begin{tabular}{|c|c|c|c|c|}
\hline Country & Adj. sample size & Lag length & ADF $t$-statistic & ADF $p$-value \\
\hline Albania & 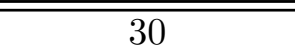 & 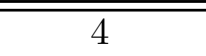 & -1.4475 & 0.825 \\
\hline Algeria & 49 & 0 & -1.8454 & 0.665 \\
\hline Angola & 49 & 0 & -1.5145 & 0.810 \\
\hline Argentina & 48 & 1 & -1.1862 & 0.900 \\
\hline Australia & 49 & 0 & -1.4229 & 0.840 \\
\hline Austria & 34 & 0 & $-3.5499^{* *}$ & 0.050 \\
\hline Bahrain & 34 & 0 & -1.7048 & 0.725 \\
\hline Bangladesh & 31 & 0 & -0.5882 & 0.975 \\
\hline Belgium & 34 & 0 & $-3.8794^{* *}$ & 0.025 \\
\hline Bolivia & 34 & 0 & -2.6466 & 0.265 \\
\hline Brazil & 49 & 0 & -0.9320 & 0.945 \\
\hline Brunei & 49 & 0 & -2.1876 & 0.485 \\
\hline Bulgaria & 34 & 0 & $-3.4229^{*}$ & 0.065 \\
\hline Cameroon & 34 & 0 & $-3.7696^{* *}$ & 0.030 \\
\hline Canada & 48 & 1 & -1.1592 & 0.905 \\
\hline Chad & 8 & 3 & $-4.6285^{* *}$ & 0.025 \\
\hline Chile & 33 & 1 & -1.0070 & 0.930 \\
\hline China & 47 & 2 & -2.7746 & 0.215 \\
\hline Colombia & 48 & 1 & -2.5481 & 0.305 \\
\hline Congo (Brazzaville) & 49 & 0 & -2.7171 & 0.235 \\
\hline Congo (Kinshasa) & 31 & 3 & $-5.6874^{* * *}$ & 0.010 \\
\hline Ivory Coast & 34 & 0 & -1.5249 & 0.800 \\
\hline Cuba & 34 & 0 & -0.8422 & 0.950 \\
\hline Denmark & 41 & 1 & -0.3380 & 0.985 \\
\hline Ecuador & 49 & 0 & $-3.6346^{* *}$ & 0.035 \\
\hline Egypt & 48 & 1 & -1.1233 & 0.915 \\
\hline Equatorial Guinea & 22 & 1 & -1.2751 & 0.865 \\
\hline Finland & 33 & 0 & -2.9025 & 0.175 \\
\hline Former Yugoslavia & 34 & 0 & -2.1927 & 0.480 \\
\hline France & 34 & 0 & -2.2750 & 0.435 \\
\hline Gabon & 48 & 1 & -2.2625 & 0.445 \\
\hline Germany & 34 & 0 & $-3.5609^{* *}$ & 0.050 \\
\hline Ghana & 34 & 0 & -0.0969 & 0.990 \\
\hline Greece & 30 & 4 & -0.6151 & 0.970 \\
\hline Guatemala & 34 & 0 & -1.0894 & 0.915 \\
\hline Hungary & 34 & 0 & -2.8605 & 0.190 \\
\hline India & 49 & 0 & -1.3149 & 0.870 \\
\hline Indonesia & 49 & 0 & -1.6924 & 0.740 \\
\hline Iran & 48 & 1 & -2.9393 & 0.160 \\
\hline Iraq & 48 & 1 & -3.1019 & 0.115 \\
\hline Israel & 33 & 1 & $-41.0519^{* * *}$ & 0.010 \\
\hline Italy & 49 & 0 & -2.3081 & 0.420 \\
\hline Japan & 34 & 0 & -1.3168 & 0.865 \\
\hline Kuwait & 49 & 0 & -1.3567 & 0.860 \\
\hline Libya & 49 & 0 & -2.7861 & 0.210 \\
\hline Malaysia & 49 & 0 & 0.3616 & 0.990 \\
\hline Mexico & 48 & 1 & -0.8416 & 0.955 \\
\hline
\end{tabular}


Table 3 - Continued from previous page

\begin{tabular}{|c|c|c|c|c|}
\hline Country & Adj. sample size & Lag length & ADF $t$-statistic & ADF $p$-value \\
\hline Mongolia & 12 & 4 & 6.3312 & 0.990 \\
\hline Myanmar & 34 & 0 & -1.4543 & 0.825 \\
\hline Netherlands & 34 & 0 & -2.7990 & 0.210 \\
\hline New Zealand & 34 & 0 & -2.0721 & 0.540 \\
\hline Nigeria & 46 & 3 & $-4.6211^{* * *}$ & 0.010 \\
\hline Norway & 42 & 1 & -0.7975 & 0.960 \\
\hline Oman & 46 & 1 & -2.0591 & 0.555 \\
\hline Pakistan & 34 & 0 & -1.5918 & 0.775 \\
\hline Papua New Guinea & 20 & 3 & -1.1534 & 0.890 \\
\hline Peru & 48 & 1 & -2.2276 & 0.465 \\
\hline Philippines & 35 & 0 & -2.6744 & 0.255 \\
\hline Poland & 33 & 1 & -2.7147 & 0.235 \\
\hline Qatar & 49 & 0 & 0.4324 & 0.990 \\
\hline Romania & 48 & 1 & -2.8559 & 0.185 \\
\hline Saudi Arabia & 49 & 0 & -2.1277 & 0.515 \\
\hline South Africa & 33 & 0 & -0.7290 & 0.960 \\
\hline Spain & 31 & 3 & -1.8028 & 0.680 \\
\hline Sudan & 21 & 0 & -0.9952 & 0.925 \\
\hline Suriname & 28 & 1 & $-3.5153^{*}$ & 0.055 \\
\hline Sweden & 30 & 0 & -1.1269 & 0.905 \\
\hline Syria & 45 & 1 & -0.2055 & 0.990 \\
\hline Thailand & 34 & 0 & -1.4850 & 0.815 \\
\hline Timor-Leste & 7 & 3 & $-12.0093^{* * *}$ & 0.010 \\
\hline Trinidad and Tobago & 48 & 1 & -2.5758 & 0.295 \\
\hline Tunisia & 48 & 0 & $-4.3545^{* * *}$ & 0.010 \\
\hline Turkey & 33 & 1 & -2.3232 & 0.410 \\
\hline United Arab Emirates & 48 & 1 & -2.6982 & 0.240 \\
\hline United Kingdom & 48 & 1 & -1.0194 & 0.930 \\
\hline United States & 48 & 1 & 0.2273 & 0.990 \\
\hline Venezuela & 49 & 0 & -1.4252 & 0.840 \\
\hline Vietnam & 28 & 0 & -0.6871 & 0.965 \\
\hline Yemen & 26 & 2 & 0.2969 & 0.990 \\
\hline Former Soviet Union & 48 & 1 & $-3.1968^{*}$ & 0.100 \\
\hline
\end{tabular}

Note: The sample period is 1965-2014. Under the alternative hypothesis, production follows a trend-stationary process. ${ }^{* * *} /{ }^{* *} /{ }^{*}$ indicates that the null hypothesis of a unit root is rejected at the $1 / 5 / 10 \%$ significance level. 
Table 4: Augmented Dickey-Fuller test for a unit root in country-level petroleum consumption

\begin{tabular}{|c|c|c|c|c|}
\hline Country & Adj. sample size & Lag length & ADF $t$-statistic & ADF $p$-value \\
\hline Afghanistan & 32 & 1 & -1.5839 & 0.775 \\
\hline Albania & 33 & 0 & -1.2356 & 0.885 \\
\hline Algeria & 48 & 1 & -0.9870 & 0.935 \\
\hline American Samoa & 30 & 3 & -1.5021 & 0.805 \\
\hline Angola & 33 & 0 & -0.2242 & 0.990 \\
\hline Antigua and Barbuda & 29 & 4 & -2.0040 & 0.575 \\
\hline Argentina & 49 & 0 & -0.3081 & 0.990 \\
\hline Aruba & 26 & 1 & -2.5089 & 0.320 \\
\hline Australia & 49 & 0 & -2.2812 & 0.435 \\
\hline Austria & 49 & 0 & -2.7126 & 0.235 \\
\hline The Bahamas & 32 & 1 & $-3.78331^{* *}$ & 0.030 \\
\hline Bahrain & 33 & 0 & -1.0888 & 0.915 \\
\hline Bangladesh & 42 & 1 & -2.3495 & 0.400 \\
\hline Barbados & 33 & 0 & $-3.6359^{* *}$ & 0.040 \\
\hline Belgium & 49 & 0 & -1.9321 & 0.620 \\
\hline Belize & 33 & 0 & -1.3530 & 0.855 \\
\hline Benin & 33 & 0 & -1.5949 & 0.770 \\
\hline Bermuda & 33 & 0 & $-3.3415^{*}$ & 0.075 \\
\hline Bolivia & 33 & 0 & -2.0131 & 0.570 \\
\hline Botswana & 33 & 0 & $-3.6617^{* *}$ & 0.040 \\
\hline Brazil & 48 & 1 & -0.9321 & 0.945 \\
\hline Brunei & 33 & 0 & -2.5682 & 0.295 \\
\hline Bulgaria & 48 & 1 & -3.0745 & 0.125 \\
\hline Burkina Faso & 33 & 0 & -3.0152 & 0.140 \\
\hline Myanmar & 32 & 1 & -1.7520 & 0.705 \\
\hline Cambodia & 33 & 0 & -1.5501 & 0.790 \\
\hline Cameroon & 33 & 0 & -0.9867 & 0.930 \\
\hline Canada & 48 & 1 & -2.4726 & 0.340 \\
\hline Cape Verde & 30 & 3 & -2.7203 & 0.235 \\
\hline Cayman Islands & 33 & 0 & -2.5794 & 0.290 \\
\hline Central African Republic & 33 & 0 & $-3.4486^{*}$ & 0.060 \\
\hline Chad & 33 & 0 & $-3.4782^{*}$ & 0.055 \\
\hline Chile & 48 & 1 & -2.1828 & 0.485 \\
\hline China & 49 & 0 & 1.2650 & 0.990 \\
\hline Colombia & 47 & 2 & -2.8201 & 0.195 \\
\hline Congo (Brazzaville) & 33 & 0 & -1.0838 & 0.915 \\
\hline Congo (Kinshasa) & 33 & 0 & -1.2739 & 0.875 \\
\hline Costa Rica & 33 & 0 & -2.8913 & 0.175 \\
\hline Ivory Coast & 33 & 0 & $-3.3237^{*}$ & 0.080 \\
\hline Cuba & 33 & 0 & -2.8214 & 0.200 \\
\hline Cyprus & 33 & 0 & -0.2157 & 0.990 \\
\hline Czech Republic & 48 & 1 & -2.6409 & 0.265 \\
\hline Denmark & 48 & 1 & -2.9869 & 0.145 \\
\hline Djibouti & 33 & 0 & -1.5787 & 0.780 \\
\hline Dominican Republic & 33 & 0 & -0.8506 & 0.950 \\
\hline Ecuador & 49 & 0 & -0.5136 & 0.980 \\
\hline Egypt & 49 & 0 & -2.1461 & 0.505 \\
\hline
\end{tabular}


Table 4 - Continued from previous page

\begin{tabular}{|c|c|c|c|c|}
\hline Country & Adj. sample size & Lag length & ADF $t$-statistic & ADF $p$-value \\
\hline El Salvador & 33 & 0 & -1.4919 & 0.810 \\
\hline Equatorial Guinea & 33 & 0 & -2.1793 & 0.485 \\
\hline Eritrea & 19 & 0 & -2.9680 & 0.165 \\
\hline Ethiopia & 33 & 0 & -1.2446 & 0.885 \\
\hline Faroe Islands & 33 & 0 & -3.0052 & 0.145 \\
\hline Fiji & 32 & 1 & -2.3698 & 0.385 \\
\hline Finland & 49 & 0 & $-3.6271^{* *}$ & 0.040 \\
\hline Former Yugoslavia & 33 & 0 & -1.6119 & 0.765 \\
\hline France & 48 & 1 & $-3.5948^{* *}$ & 0.040 \\
\hline French Guiana & 32 & 1 & -0.0456 & 0.990 \\
\hline French Polynesia & 29 & 4 & -2.8153 & 0.205 \\
\hline Gabon & 33 & 0 & -1.9578 & 0.600 \\
\hline Gambia & 33 & 0 & -1.6609 & 0.745 \\
\hline Germany & 49 & 0 & $-3.6668^{* *}$ & 0.035 \\
\hline Ghana & 33 & 0 & -1.1373 & 0.905 \\
\hline Gibraltar & 33 & 0 & -3.0048 & 0.145 \\
\hline Greece & 49 & 0 & 1.8889 & 0.990 \\
\hline Greenland & 33 & 0 & -2.5237 & 0.315 \\
\hline Guadeloupe & 33 & 0 & -2.1896 & 0.480 \\
\hline Guam & 33 & 1 & -2.8731 & 0.180 \\
\hline Guatemala & 33 & 0 & -1.9867 & 0.585 \\
\hline Guinea & 33 & 0 & $-3.9839^{* *}$ & 0.020 \\
\hline Guinea-Bissau & 30 & 3 & -2.1847 & 0.480 \\
\hline Guyana & 32 & 1 & -2.8762 & 0.185 \\
\hline Haiti & 33 & 0 & -2.7893 & 0.210 \\
\hline Honduras & 33 & 0 & -2.7099 & 0.240 \\
\hline Hong Kong & 49 & 0 & -1.7619 & 0.705 \\
\hline Hungary & 49 & 0 & -2.3560 & 0.395 \\
\hline Iceland & 34 & 0 & -0.8769 & 0.945 \\
\hline India & 49 & 0 & -0.2524 & 0.990 \\
\hline Indonesia & 49 & 0 & -2.4291 & 0.360 \\
\hline Iran & 49 & 0 & -3.1569 & 0.105 \\
\hline Iraq & 33 & 0 & -2.9118 & 0.170 \\
\hline Ireland & 48 & 1 & -1.8595 & 0.660 \\
\hline Israel & 49 & 0 & -1.2078 & 0.895 \\
\hline Italy & 49 & 0 & -2.0495 & 0.560 \\
\hline Jamaica & 32 & 1 & -1.8304 & 0.665 \\
\hline Japan & 49 & 0 & -2.6704 & 0.250 \\
\hline Jordan & 33 & 0 & -2.3839 & 0.380 \\
\hline Kenya & 33 & 0 & -2.3102 & 0.415 \\
\hline Kuwait & 49 & 0 & -1.2534 & 0.885 \\
\hline Laos & 30 & 3 & -0.2245 & 0.990 \\
\hline Lebanon & 33 & 0 & -2.2132 & 0.465 \\
\hline Lesotho & 33 & 0 & $-5.9807^{* * *}$ & 0.010 \\
\hline Liberia & 33 & 0 & -1.3801 & 0.850 \\
\hline Libya & 33 & 0 & $-3.9823^{* *}$ & 0.020 \\
\hline Luxembourg & 33 & 1 & -1.4248 & 0.835 \\
\hline Macau & 33 & 0 & -1.5074 & 0.805 \\
\hline
\end{tabular}


Table 4 - Continued from previous page

\begin{tabular}{|c|c|c|c|c|}
\hline Country & Adj. sample size & Lag length & ADF $t$-statistic & ADF $p$-value \\
\hline Madagascar & 33 & 0 & -1.5979 & 0.770 \\
\hline Malawi & 33 & 0 & -1.8363 & 0.660 \\
\hline Malaysia & 49 & 0 & -1.8905 & 0.645 \\
\hline Maldives & 33 & 0 & -2.7696 & 0.215 \\
\hline Mali & 32 & 1 & $-3.6629^{* *}$ & 0.040 \\
\hline Malta & 33 & 0 & -1.7093 & 0.720 \\
\hline Martinique & 33 & 0 & -2.0828 & 0.535 \\
\hline Mauritania & 33 & 0 & -0.9561 & 0.935 \\
\hline Mauritius & 33 & 0 & -2.5584 & 0.300 \\
\hline Mexico & 49 & 0 & 0.6512 & 0.990 \\
\hline Mongolia & 33 & 0 & 0.0113 & 0.990 \\
\hline Morocco & 33 & 0 & -0.4795 & 0.980 \\
\hline Mozambique & 33 & 0 & -1.8210 & 0.670 \\
\hline Namibia & 19 & 4 & -2.6599 & 0.260 \\
\hline Nepal & 33 & 0 & -1.9466 & 0.605 \\
\hline Netherlands & 49 & 0 & -1.8209 & 0.680 \\
\hline Netherlands Antilles & 34 & 0 & -0.5557 & 0.975 \\
\hline New Caledonia & 33 & 0 & -0.7687 & 0.960 \\
\hline New Zealand & 49 & 0 & -1.4113 & 0.845 \\
\hline Nicaragua & 33 & 0 & -0.6729 & 0.965 \\
\hline Niger & 33 & 0 & -1.0842 & 0.915 \\
\hline Nigeria & 34 & 0 & -2.2462 & 0.450 \\
\hline North Korea & 32 & 1 & -2.3616 & 0.390 \\
\hline Norway & 49 & 0 & $-3.8401^{* *}$ & 0.025 \\
\hline Oman & 30 & 3 & $-7.7716^{* * *}$ & 0.010 \\
\hline Pakistan & 46 & 3 & -2.8753 & 0.180 \\
\hline Palestinian Territories & 16 & 0 & -1.6218 & 0.740 \\
\hline Panama & 30 & 3 & $-3.5672^{* *}$ & 0.050 \\
\hline Papua New Guinea & 33 & 0 & -0.7451 & 0.960 \\
\hline Paraguay & 33 & 0 & -0.5885 & 0.970 \\
\hline Peru & 48 & 1 & -1.4156 & 0.845 \\
\hline Philippines & 49 & 0 & -1.3669 & 0.855 \\
\hline Poland & 48 & 1 & -2.7663 & 0.215 \\
\hline Portugal & 46 & 3 & -1.0507 & 0.925 \\
\hline Puerto Rico & 33 & 0 & -0.1843 & 0.990 \\
\hline Qatar & 32 & 1 & -1.7025 & 0.725 \\
\hline Reunion & 33 & 0 & -0.6138 & 0.970 \\
\hline Romania & 49 & 0 & -2.3297 & 0.410 \\
\hline Rwanda & 33 & 0 & -1.3933 & 0.845 \\
\hline Saudi Arabia & 49 & 0 & 0.1454 & 0.990 \\
\hline Senegal & 33 & 0 & -0.8011 & 0.955 \\
\hline Seychelles & 33 & 0 & -0.6179 & 0.970 \\
\hline Sierra Leone & 34 & 0 & -0.7923 & 0.955 \\
\hline Singapore & 49 & 0 & -0.6049 & 0.975 \\
\hline Slovakia & 49 & 0 & -2.6181 & 0.275 \\
\hline Somalia & 34 & 0 & -1.2223 & 0.890 \\
\hline South Africa & 49 & 0 & -2.9739 & 0.150 \\
\hline South Korea & 49 & 0 & -1.1181 & 0.915 \\
\hline
\end{tabular}


Table 4 - Continued from previous page

\begin{tabular}{l|cccc}
\hline Country & Adj. sample size & Lag length & ADF $t$-statistic & ADF $p$-value \\
\hline Spain & 46 & 3 & -2.5675 & 0.300 \\
Sri Lanka & 33 & 0 & -1.0886 & 0.915 \\
Sudan & 30 & 3 & -3.0661 & 0.130 \\
Suriname & 34 & 0 & -0.8060 & 0.955 \\
Swaziland & 34 & 0 & -1.2300 & 0.885 \\
Sweden & 49 & 0 & $-3.2349^{*}$ & 0.090 \\
Switzerland & 49 & 0 & $-3.3080^{*}$ & 0.075 \\
Syria & 29 & 4 & -1.1917 & 0.895 \\
Taiwan & 49 & 0 & -0.7636 & 0.960 \\
Tanzania & 31 & 2 & -2.4139 & 0.365 \\
Thailand & 48 & 1 & -2.0430 & 0.565 \\
Togo & 33 & 0 & -1.2563 & 0.880 \\
Trinidad and Tobago & 49 & 0 & -2.1302 & 0.515 \\
Tunisia & 33 & 0 & -2.4816 & 0.335 \\
Turkey & 49 & 0 & -1.7619 & 0.705 \\
Uganda & 29 & 4 & 6.1265 & 0.990 \\
United Arab Emirates & 49 & 0 & 0.0588 & 0.990 \\
United Kingdom & 49 & 0 & $-3.2175^{*}$ & 0.095 \\
United States & 48 & 1 & -3.0728 & 0.125 \\
Uruguay & 33 & 0 & -1.8204 & 0.670 \\
Venezuela & 49 & 0 & -2.2747 & 0.435 \\
Vietnam & 46 & 3 & -1.8901 & 0.645 \\
Virgin Islands, U.S. & 33 & 0 & -1.9992 & 0.580 \\
Wake Island & 29 & 4 & 0.8315 & 0.990 \\
Western Sahara & 33 & 0 & -1.1380 & 0.905 \\
Yemen & 33 & 0 & -0.8129 & 0.955 \\
Zambia & 31 & 0 & -2.2099 & 0.470 \\
Zimbabwe & 31 & 0 & -1.1188 & 0.910 \\
Former Soviet Union & 48 & 1 & -2.4878 & 0.335 \\
\hline
\end{tabular}

Note: The sample period is 1965-2014. Under the alternative hypothesis, consumption follows a trend-stationary process. ${ }^{* * *} /{ }^{* *} /{ }^{*}$ indicates that the null hypothesis of a unit root is rejected at the $1 / 5 / 10 \%$ significance level. 
Figure 1: Cumulated hydrocarbon volumes in mmboe of giant oil fields by their year of discovery

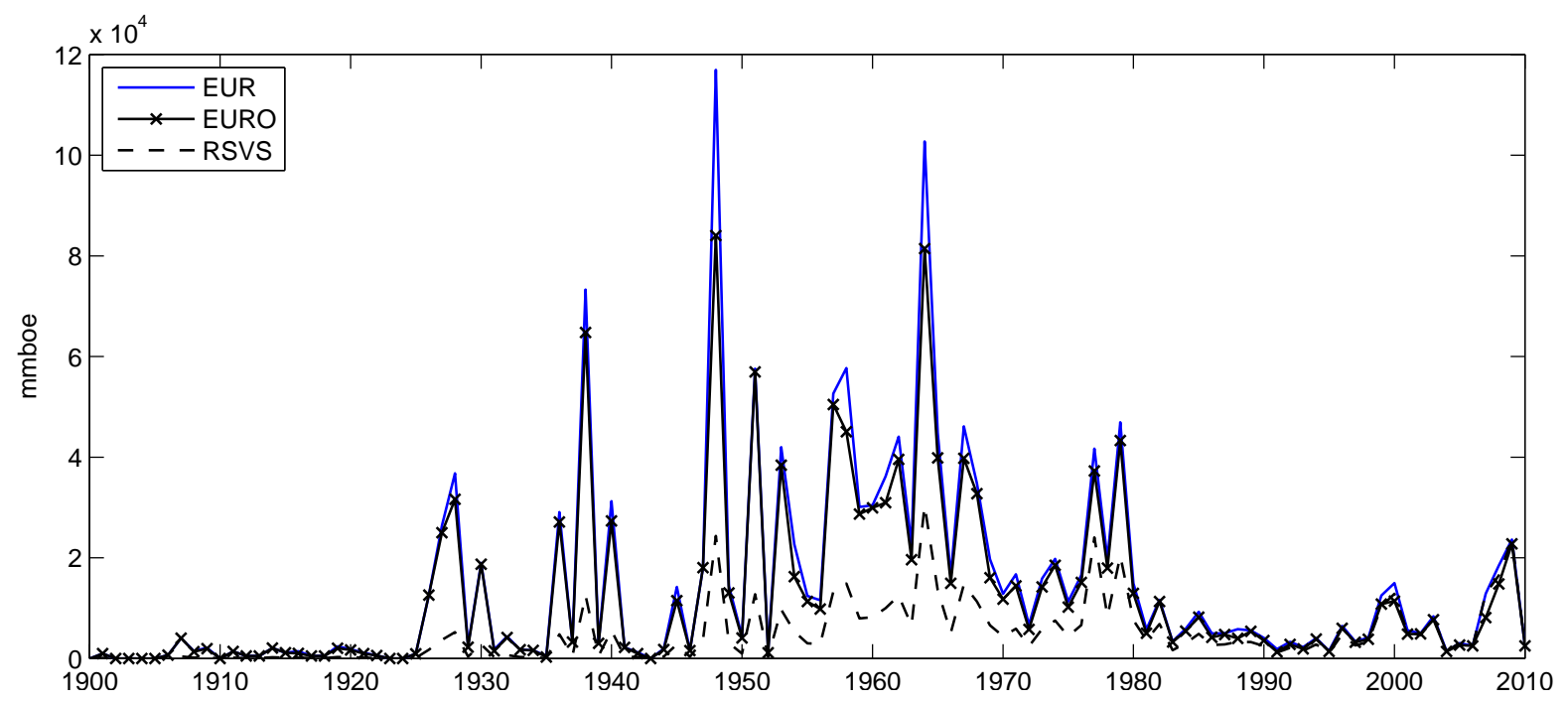

Figure 2: Impulse response of cumulated changes in country-level petroleum production to a giant oil field discovery based on the dynamic panel DLR model in (1)
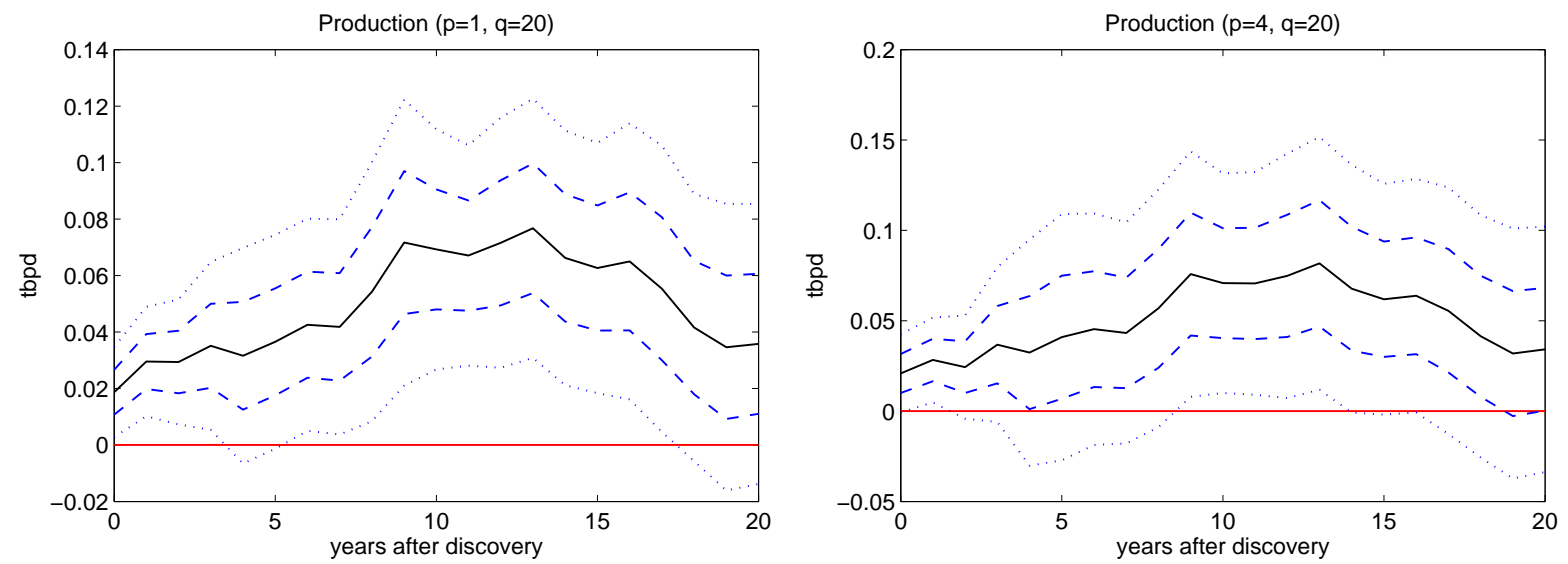

Note: Point estimates with one- and two-standard-error HAC-robust confidence intervals based on 1,000 bootstrap replications 
Figure 3: Impulse response of cumulated changes in OPEC and non-OPEC production to a giant oil field discovery based on the dynamic panel DLR model in (3)
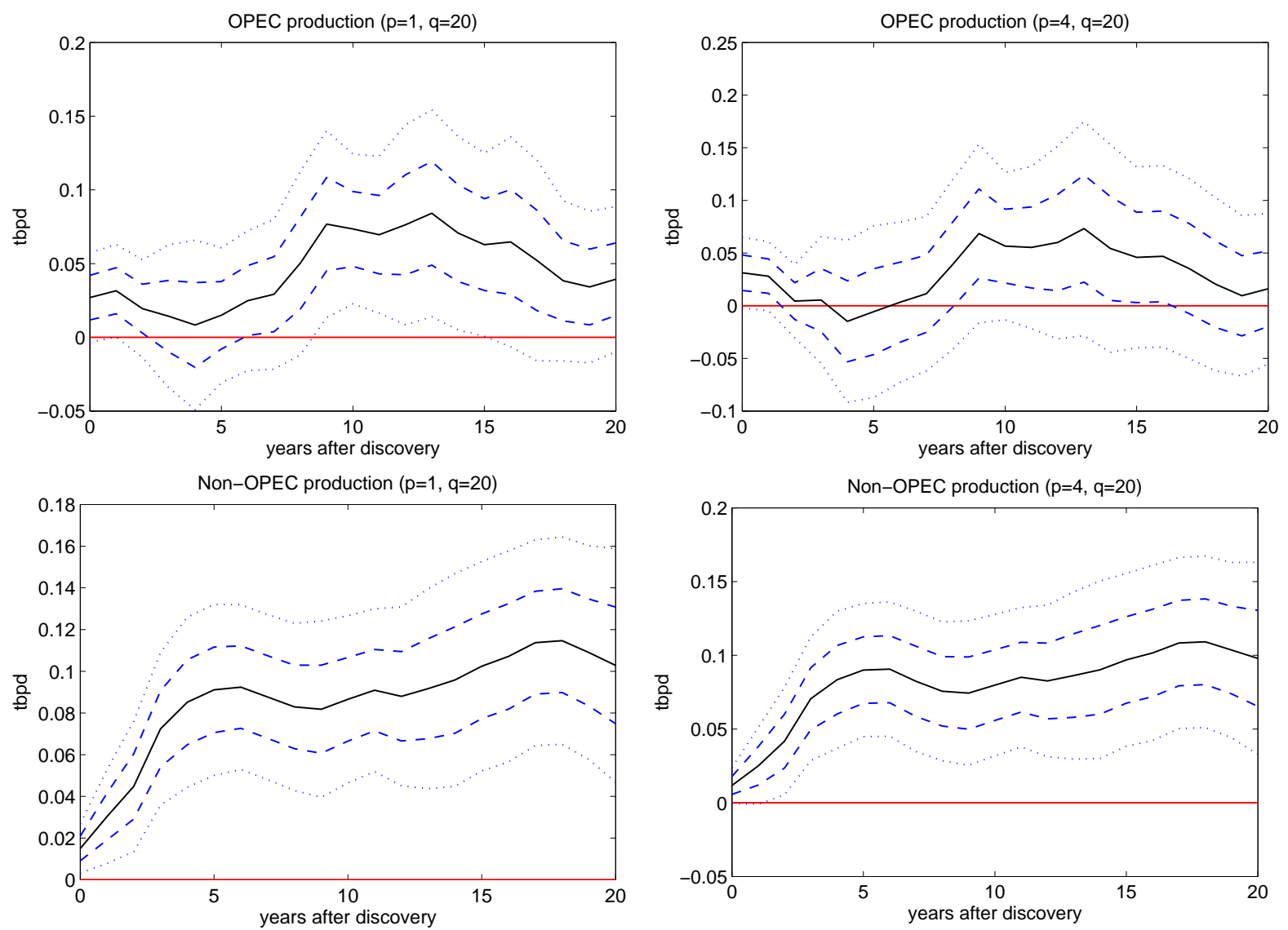

Note: Point estimates with one- and two-standard-error HAC-robust confidence intervals based on 1,000 bootstrap replications 
Figure 4: Impulse response of cumulated changes in production to giant onshore and offshore oil field discoveries based on the dynamic panel DLR model in (5)
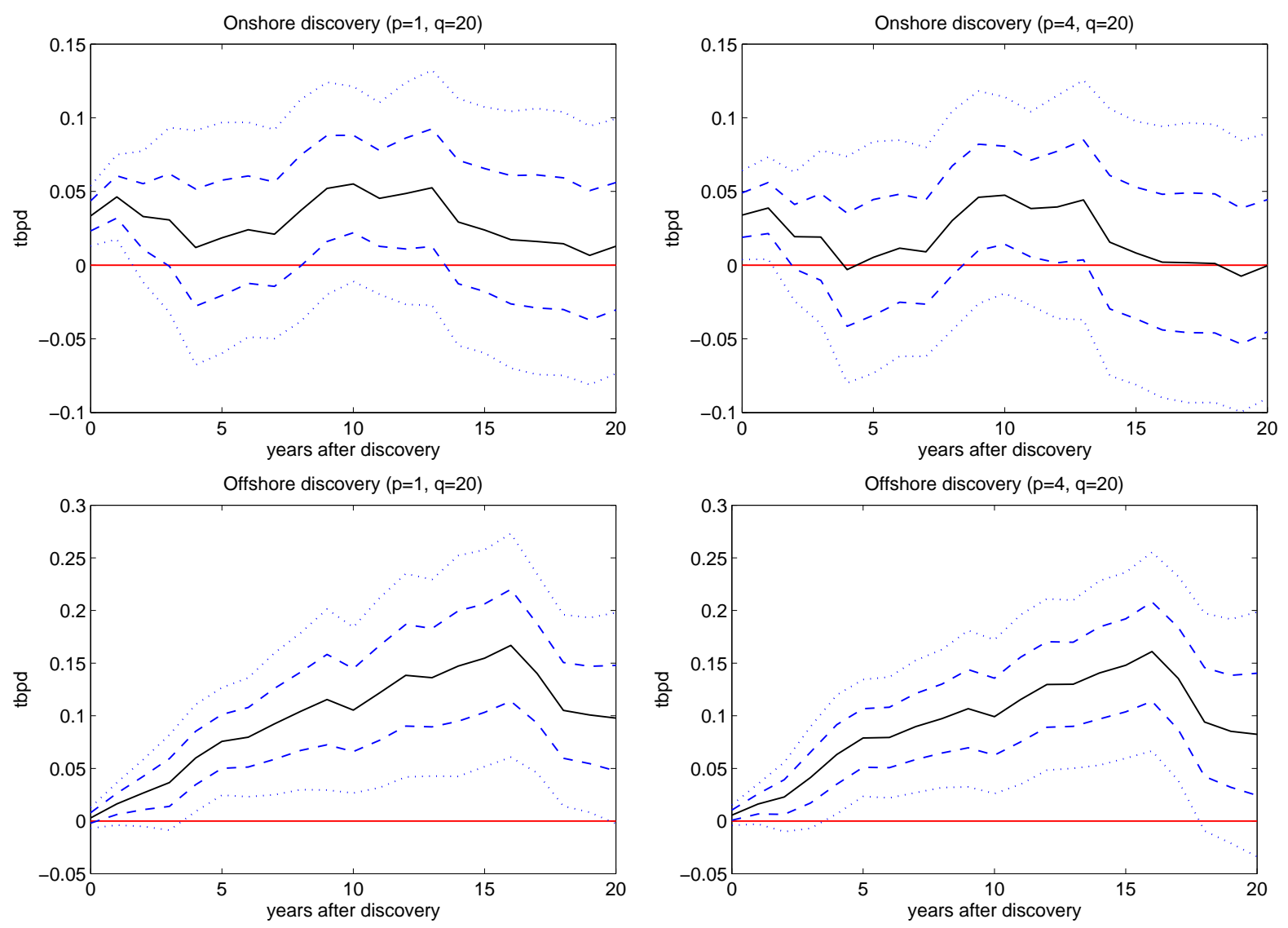

Note: Point estimates with one- and two-standard-error HAC-robust confidence intervals based on 1,000 bootstrap replications 
Figure 5: Impulse response of cumulated changes in production to giant and super-/mega-giant oil field discoveries based on the dynamic panel DLR model in (7)
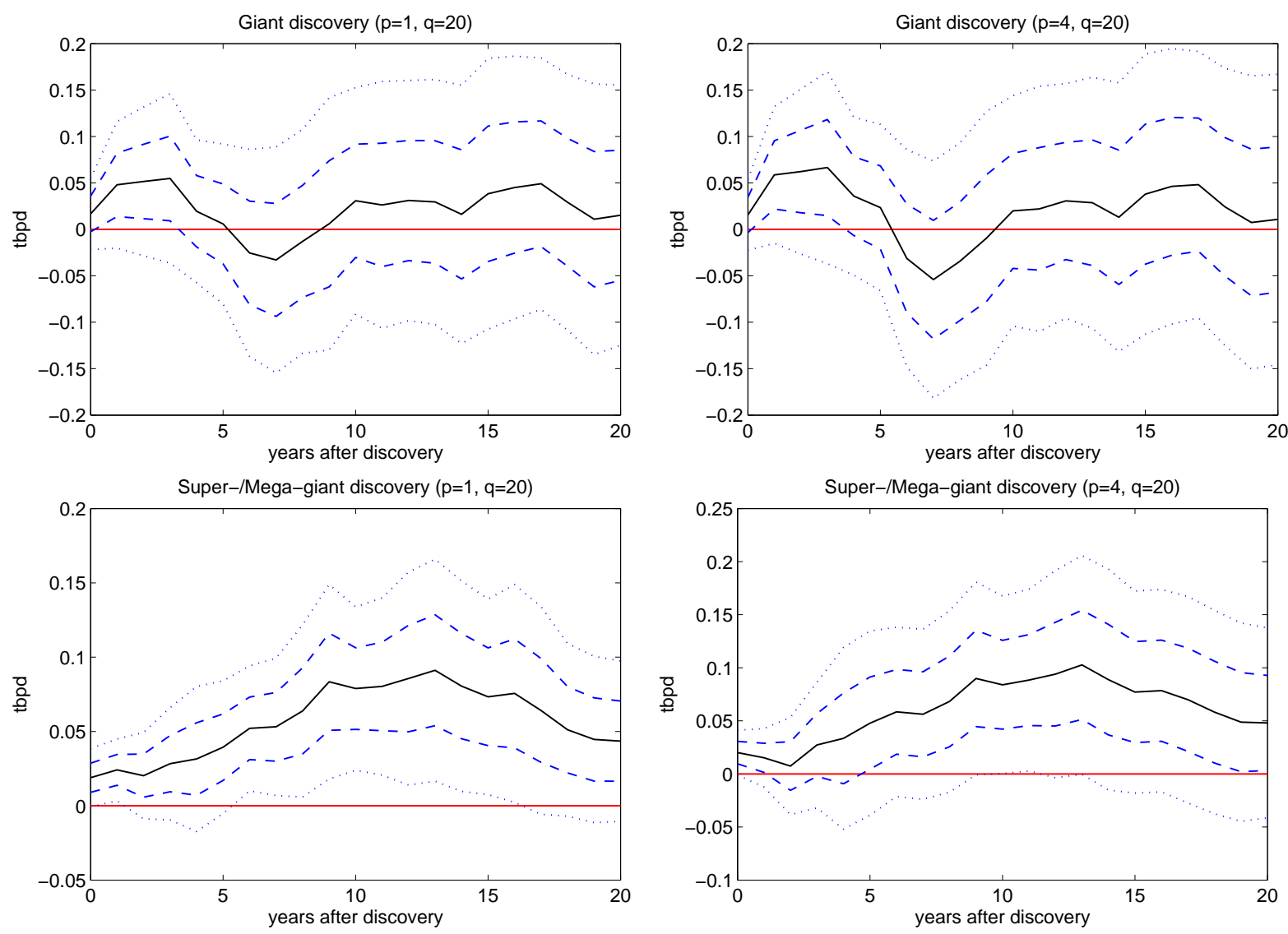

Note: Point estimates with one- and two-standard-error HAC-robust confidence intervals based on 1,000 bootstrap replications 
Figure 6: Impulse response of cumulated changes in country-level petroleum consumption to a giant oil field discovery based on the dynamic panel DLR model in (1)
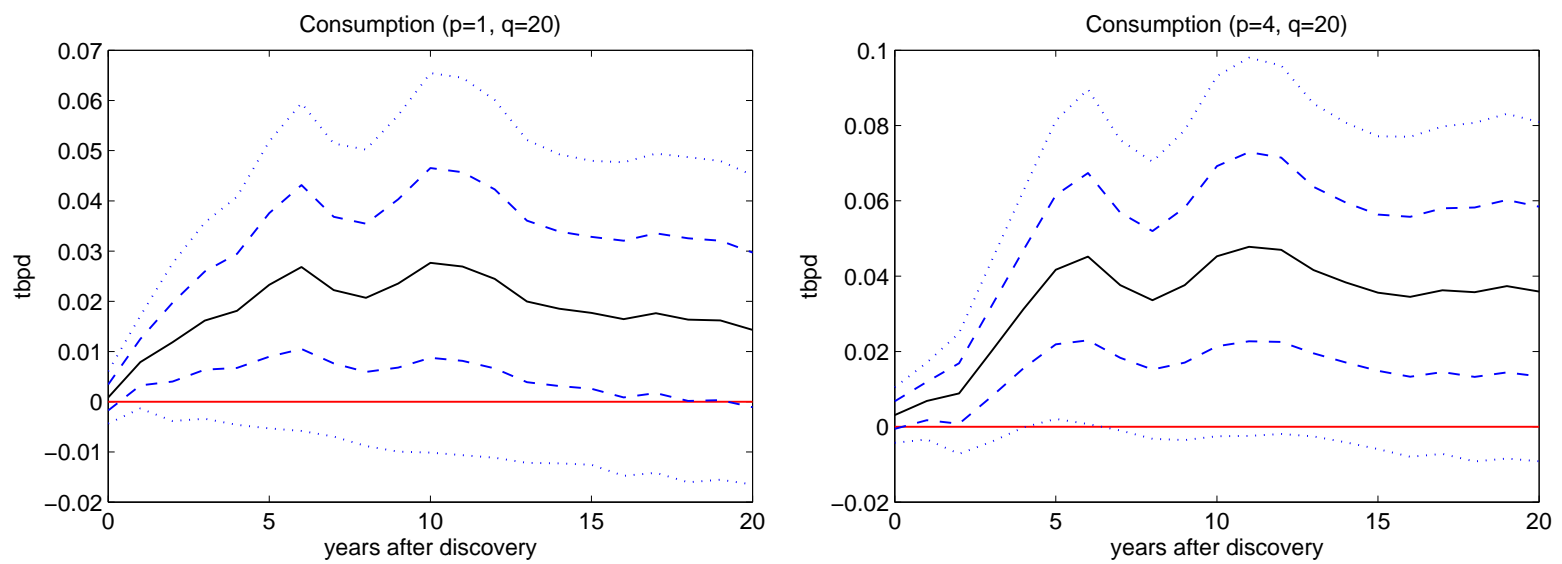

Note: Point estimates with one- and two-standard-error HAC-robust confidence intervals based on 1,000 bootstrap replications

Figure 7: Impulse response of cumulated changes in OPEC and non-OPEC consumption to a giant oil field discovery based on the dynamic panel DLR model in (3)
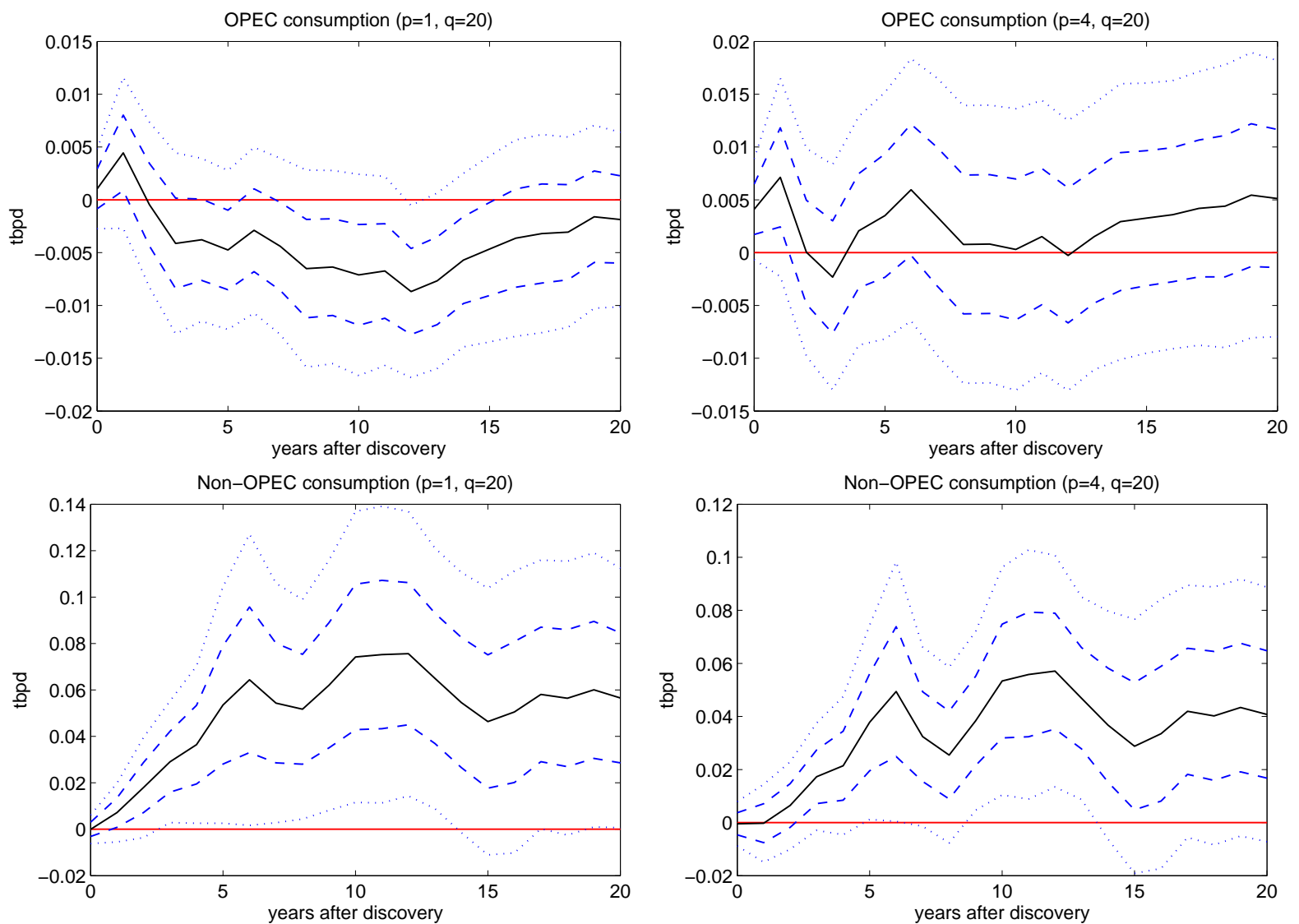

Note: Point estimates with one- and two-standard-error HAC-robust confidence intervals based on 1,000 bootstrap replications 